\title{
1. Uma abordagem da literatura e cultura em Moçambique
}

\author{
Ubiratã Souza
}

\section{SciELO Books / SciELO Livros / SciELO Libros}

SOUZA, U. Uma abordagem da literatura e cultura em Moçambique. In: Entre palavras e armas: literatura e guerra civil em Moçambique [online]. São Bernardo do Campo, SP: Editora UFABC, 2017, pp. 17-75. ISBN: 978-85-68576-92-2. https://doi.org/10.7476/9788568576922.0002.

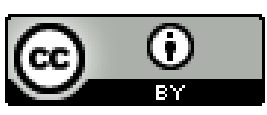

All the contents of this work, except where otherwise noted, is licensed under a Creative Commons Attribution 4.0 International license.

Todo o conteúdo deste trabalho, exceto quando houver ressalva, é publicado sob a licença Creative Commons Atribição 4.0.

Todo el contenido de esta obra, excepto donde se indique lo contrario, está bajo licencia de la licencia $\underline{\text { Creative }}$ Commons Reconocimento 4.0. 


\section{Uma abordagem da literatura e cultura em Moçambique}

\subsection{Um posicionamento para pensar a literatura na sociedade}

Nossa hipótese de leitura dos romances Neighbours (1995) e Os sobreviventes da noite (2008) baseia-se na tentativa de compreender as relações que esses textos estabelecem com a guerra civil em Moçambique Se o objetivo, por um lado, é realizar uma análise literária a partir da qual seja possível obter argumentos estéticos que deverão ser interpretados historicamente, por outro lado é, de igual modo, uma interpretação social do próprio conflito armado, de modo a compreender o texto estético como um produto social e comunicativo de cultura que, de alguma maneira, expressa posições públicas individuais e coletivas em relação às dinâmicas sócio-históricas vividas naquele período. Essa expressão pública de posições através do produto estético depende, por sua vez, de uma articulação específica da própria linguagem literária, que aqui será vista como uma estratégia discursiva com implicações na ordem do social, estabelecendo suas relações com a mais variada gama de campos distintos da sociedade, com suas respectivas organizações próprias: desde a economia, às configurações ideológicas, até a configuração política e jurídica de uma sociedade numa baliza cronológica específica. É justamente por isso que, embora a etapa de análise literária dependa da verificação 
e estudo das articulações estéticas assim como elas se encontram no interior do próprio texto literário, a etapa interpretativa dos dados estéticos obtidos na análise depende do apoio de diversas outras ciências humanas, quais sejam a historiografia, a sociologia, a ciência política, a antropologia, a economia, da filologia e da linguística - e justamente por isso esse trabalho de interpretação histórica da literatura é essencialmente interdisciplinar.

Ao adotarmos essa postura epistemológica diante da literatura e da sociedade concomitantemente, estamos fazendo referência a uma corrente de pensamento que prognostica, a propósito, que qualquer sociedade existe sobre uma base material econômica que apresenta articulações específicas que produzirão impacto e homologias em todas as demais esferas dessa sociedade - inclusive na articulação da linguagem estética no interior de um texto literário. Essa corrente de pensamento que inscreve o estudo literário no campo das ciências humanas mais do que no campo de qualquer "beletrismo" é o próprio materialismo dialético, como este se compôs desde os princípios materialistas formulados por Marx e Engels, e posteriormente continuado, revisitado, reformulado e extrapolado por um sem número de outros teóricos da cultura, da literatura da história, da própria sociologia e da ciência política. $\mathrm{O}$ materialismo cultural é uma corrente de pensamento, como qualquer outra, muito antiga e cheia de vicissitudes e diferenças internas, que por vezes culminaram em debates acalorados cheios de extremos e dogmatismos. Justamente por isso é que é preciso, ainda que dentro do espectro materialista, definir precisamente quais as posições mais convenientes a uma fundamentação epistemológica acerca da pesquisa em literatura em África. Propomos neste capítulo uma revisita a pontos fundamentais desse debate, a consequente mobilização de conceitos chaves de certas formulações teóricas específicas, e investigar de que modo esses conceitos podem ou não ser úteis para uma análise histórica da cultura moçambicana. Para essa mobilização, 
no entanto, será preciso revisitar essas vozes, ouvi-las falar, e fazer com que falem umas com as outras, quase como num exercício de leitura.

O materialismo econômico que embasa a teoria social de Marx e Engels objetivou como meta maior a análise do modo de produção capitalista e, por conseguinte, a formulação de algumas propostas para a supressão radical desse modo, visando ao fim da desigualdade social composta ao longo dos séculos pela propriedade privada e pela acumulação de capital. Trata-se, portanto, de estudar a composição histórica da sociedade capitalista tendo em vista justamente sua transformação; e a ênfase na transformação é o que faz a teoria de Marx dialética (KONDER, 2008, p. 34, NETTO, 2006, p. 19). A partir desse pressuposto inicial, algumas noções chaves como sociedade de classe, classe trabalhadora e revolução foram formuladas. Situar a literatura num discurso crítico diante dessa postura teórica básica talvez não tenha sido tarefa tão fácil, mas em muitos aspectos isso pode até parecer óbvio, já que podem existir certos indicativos inelutáveis no interior de algumas obras que apontam justamente para essa possibilidade.

Embora Marx e Engels não tenham dedicado um livro sequer a uma teoria da cultura ou da estética, referiram-se diversas vezes a romances e outras obras, além do que a arte e a cultura nunca estiveram alheias ao seu espectro analítico, e eles, em pequenas indicações esparsas, acabaram por lançar as bases do que seria uma corrente de pensamento estético-cultural cujos rudimentos de formulações presentes em seus escritos seriam trabalhados e retrabalhados posteriormente por vários outros teóricos. Justamente por isso Terry Eagleton (2011b, p. 13) considera que todo o sistema de ideias sobre cultura e estética que derivou do materialismo de Marx e Engels é muito mais do que a simples hermenêutica dos filósofos: é uma miríade de derivações teóricas que buscam explicitar os procedimentos epistemológicos presentes na proposta inicial dos dois pensadores acerca da literatura e da arte. Pode-se dizer que um dos principais fundamentos do pensamento 
marxista sobre estética e cultura seja aquilo que temos chamado até aqui de "princípio materialista", uma formulação epistemológica e filosófica arrojada e simples, entretanto, que abarca a um tempo desde a economia até as funções cognitivas humanas. Seu fundamento mais consagrado se encontra na seguinte passagem, escrita por Karl Marx, de A ideologia alemã, obra de 1846 (MARX; ENGELS, 2010, p. 99):

A produção das ideias e representações, da consciência, aparece a princípio diretamente entrelaçada à atividade material e ao intercâmbio material dos homens, como a linguagem da vida real. As representações, o modo de pensar, a comunicação espiritual entre os homens se apresentam aqui ainda como emanação direta da sua relação material, tal como se manifesta na linguagem da política, das leis, da moral, da religião, da metafísica etc. de um povo. Os homens são os produtores de suas representações, das suas ideias etc. - mas se trata de homens reais e ativos, condicionados por um determinado desenvolvimento das suas forças produtivas e pelo intercâmbio a ele correspondente, inclusive suas formas mais desenvolvidas.

Segundo o que podemos observar nessa proposta, o desenvolvimento de forças produtivas no campo da economia estaria "diretamente entrelaçado" às "ideias e representações" geradas no seio da sociedade; entenda-se por “ideias e representações”, conforme é possível depreender do escrito, o modo de pensar, a comunicação espiritual (a arte inclusa), a política (sua linguagem), as leis, a moral, a religião etc. Assim sendo, uma crítica literária interessada em conceber sua metodologia baseada no princípio materialista deve correr o risco de analisar uma obra de modo que seja possível articulá-la, de algum modo, às condições materiais do período em que é produzida, uma vez que a arte e a literatura, como produtos de "ideias e representações", são elementos humanos produzidos por indivíduos situados num momento específico de uma sociedade específica, cujas formas de pensar e agir 
estão diretamente relacionadas às atividades materiais que estruturam essa sociedade.

Trata-se, basicamente, de admitir, no campo epistemológico, que a forma como um indivíduo historicamente situado articula suas estruturas de pensamento apresenta relações verificáveis, do ponto de vista analítico, às formas como obtém seu alimento e logra subsistir materialmente na vida social. Assim sendo, se até as estruturas de pensamento afetam-se pelas homologias inerentes à existência material, quanto mais não seria possível obter essas relações no interior de uma análise na forma como os textos literários se articulam, tanto no nível da linguagem quanto nas relações que estabelecem entre outros textos e com todas as dinâmicas da tal existência material de onde advém.

Proceder a uma análise literária baseando-se no materialismo marxista, portanto, é tratar de literatura, mas, simultaneamente, transcendê-la para a própria configuração de uma sociedade específica no momento em que a obra é escrita, lida e recebida - claro, na hipótese de que esta análise consiga alcançar seus objetivos. Ao fazer isso, portanto, colocamos a crítica num ponto equidistante entre a literatura e a história social, ou mesmo da sociologia histórica. Convém ressaltar que para a crítica literária motivada por tal postura teórica não deveria interessar, ao menos em tese, nem aquele tipo de discurso sobre o literário que se centrasse abstratamente sobre os significados unicamente estruturais de uma obra, desinteressando-se pelas implicações na ordem do histórico e do social decorrentes da significação produzida pela linguagem articulada esteticamente; outrossim, tampouco deveria interessar aquele outro tipo de discurso sobre o literário que se furtasse a proceder as análises no âmbito da articulação da linguagem para tratar somente das questões sócio-históricas, eventualmente patentes ao texto literário ou não. Afinal, a crítica materialista não deveria ser o trabalho de comparar um texto a uma suposta "realidade social externa”, já que, para essa teoria, tanto a sociedade 
se compõe desde suas bases até o pensamento como um todo compósito, assim como a literatura só existe em face de uma existência social situada historicamente. É por isso que Terry Eagleton (2011b, p. 2) alerta para o desafio que se impõe à crítica materialista ao perseguir o meio termo, justamente equidistante, entre o estrutural e o social, entre o estético e o histórico:

A crítica marxista não é meramente uma "sociologia da literatura", dedicada à maneira como os romances são publicados e como eles mencionam (ou não) a classe trabalhadora. Seu objetivo é explicar a obra literária de forma mais plena; e isso significa uma atenção sensível às suas formas, estilos e significados. Mas isso também significa compreender essas formas, estilos e significados como produtos de uma História específica.

É por isso que o materialismo marxista apresenta um fundo econômico, mas muitas vezes é chamado de materialismo histórico: não deveria nunca se desviar das análises sociais e históricas que miram o desenvolvimento das forças de produção de um período e, ainda, ao analisar uma obra de arte, não entende que seja possível alheia a essas questões. Uma vez que é motivada a analisar questões pertinentes ao desenvolvimento das forças produtivas que condicionam e organizam uma sociedade numa baliza cronológica específica, o que deve estar, por princípio, invocado pela organização estética de um texto literário, a crítica materialista abre uma faceta de diálogo franco com a historiografia social, uma vez que ambas as formas de construção do conhecimento se complementam nessa epistemologia dialética, iluminando aspectos diversos, mas complementares, relativos aos movimentos das sociedades humanas.

Essa postura epistemológica inicial do materialismo histórico de Marx, no entanto, é só o princípio. Ao formular que as ideias e representações estão "diretamente entrelaçadas" ao desenvolvimento 
de formas de produção de uma sociedade num momento específico, temos o pressuposto, mas não temos nenhuma explicitação dos detalhes metodológicos desse processo. Ou seja, como exatamente se relacionam as ideias e representações ao desenvolvimento das formas de produção? Outrossim, de que modo uma crítica literária pode apreender as homologias e pressões desempenhadas pelas condições econômicas, sociais e históricas sobre um texto literário? Essa pergunta, na verdade, procura investigar como, a partir do pressuposto epistemológico inicial do materialismo histórico conforme formulado por Marx e Engels, podemos extrair um método de análise que consiga obter resultados significativos para a relação entre o desenvolvimento das formas produtivas e as ideias e representações.

A investigação por esse método de análise parece ter sido justamente a contribuição de inúmeros teóricos marxistas posteriores a Marx. E essa é uma lista bem numerosa, que aglomera nomes tão importantes quanto díspares em suas concepções teóricas: como exemplos, podemos citar Trótski, Lukács, Gramsci, Adorno até, Benjamin e Horkheimer, Althusser; mais recentemente, temos Raymond Williams, Fredric Jameson, Terry Eagleton, entre muitos outros. No entanto, querer aglomerar as diversas tendências que cada um dos pensadores marxistas representa dentro de alguma unidade coesa seria praticamente uma utopia. Por isso, faz-se necessário realizar um recorte específico de conceitos que se queira minimamente coerente para seguir caminho. No entanto, para o leitor de literatura que busca dentro dessa diversidade de abordagens uma postura epistemológica e, simultaneamente, um instrumental metodológico para a sua análise de textos artísticos, uma pequena dose de ecletismo é sempre inevitável, colhendo de cada um dos lados desse imenso caleidoscópio aquilo que melhor lhe convirá.

Existe uma categoria clássica do pensamento materialista que busca esclarecer justamente o processo que configura a articulação 
entre as ideias e representações e o desenvolvimento das formas de produção através da construção de um esquema baseado em duas ordens de procedência: uma infraestrutura econômica determinante e uma superestrutura determinada. Esses termos se transformaram em verdadeiros conceitos da tradição marxista, e se originaram de uma peculiar interpretação deste longo trecho de Marx, de 1859, na obra Contribuição à crítica da economia política (MARX; ENGELS, 2010, p. 97):

Na produção social da sua vida, os homens estabelecem relações determinadas, necessárias e independentes de sua vontade, relações de produção que correspondem a uma dada fase de desenvolvimento das suas forças produtivas materiais. A totalidade destas relações de produção constitui a estrutura econômica da sociedade, a base real sobre a qual se ergue uma superestrutura jurídica e política e a que correspondem determinadas formas de consciência social. O modo de produção da vida material condiciona o processo da vida social, política e espiritual em geral. Não é a consciência social que determina o seu ser, mas, ao contrário, é o seu ser social que determina a sua consciência. Ao chegar a uma determinada fase de desenvolvimento, as forças produtivas materiais da sociedade entram em contradição com as relações de produção existentes ou, o que não é mais que a sua expressão jurídica, com as relações de propriedade no interior das quais se tinham movido até então. De formas de desenvolvimento das forças produtivas, estas relações se convertem em suas travas. E assim se abre uma época de revolução social. Transformando-se a base econômica, transforma-se mais ou menos rapidamente, toda a imensa superestrutura erigida sobre ela. No estudo dessas transformações, há que se distinguir sempre entre as transformações materiais das condições econômicas, que podem ser verificadas com a exatidão própria das ciências naturais, e as formas jurídicas, políticas, religiosas, artísticas ou filosóficas - numa palavra, as formas ideológicas através das quais os homens adquirem consciência deste conflito e lutam para resolvê-lo. 
A partir dessas formulações funcionais e circunstanciais dos termos "superestrutura" e "base econômica" é que parece ter surgido uma tradição toda que consagrou esses termos como conceitos chaves do marxismo. Como esclarece Eagleton (2011b, p. 18), o uso desses dois termos foi uma maneira útil para elaborar uma maior sistematização que contribuísse para a análise da questão de como as ideias e representações estão "diretamente entrelaçadas" ao desenvolvimento de formas de produção de uma sociedade num momento específico: toda a sociedade poderia, portanto, de acordo com o entendimento conceitual dos termos, ser analisada em face de uma organização jurídica, política, religiosa, entre outras, que comporia uma superestrutu$r a$, diretamente subordinada a uma infraestrutura, que seria uma base econômica, abarcando a totalidade das relações de produção dessa mesma sociedade.

Raymond Williams, em análise a esse momento da crítica de arte marxista, alerta para certo perigo que rondou o uso desses termos como conceitos. Ele considera importante compreender que o uso aleatório e esporádico desses termos por Marx fazia parte somente de uma "exposição do método histórico materialista de compreender as relações jurídicas e as formas do Estado” (WILLIAMS, 1979, p. 80). Williams chama atenção justamente para o fato de que o uso desses termos, de acordo com o original alemão, agrega uma grande diversidade de significados e sentidos distintos uns dos outros. $\mathrm{O}$ perigo a que se referia Williams no uso conceitual dos termos era justamente de seu uso se enrijecer ao ponto de que esses conceitos, superestrutura e infraestrutura, representassem áreas distintas da sociedade que pudessem ser analisadas individualmente. Segundo afirma (1979, p. 82):

Na transição de Marx para o marxismo, e em seguida no desenvolvimento de formulações expositivas e didáticas, as palavras usadas na argumentação original foram projetadas, primeiro, como se fossem conceitos precisos, e, segundo, como se fossem termos descritivos para "áreas" observáveis 
da vida social. O principal significado das palavras nos argumentos originais foi de relação, mas a popularidade dos termos tendeu a indicar: a) categorias relativamente fechadas, ou $b$ ) áreas relativamente fechadas de atividade. Estas então foram correlacionadas, seja temporalmente (primeiro a produção material, em seguida a consciência, depois a política e a cultura) ou com efeito, forçando a metáfora, espacialmente ("níveis" ou "camadas" visíveis e distinguíveis - política e cultura, em seguida formas de consciência e assim por diante, até "a base" ou "infraestrutura"). Os sérios problemas práticos do método, que as palavras originais haviam indicado, foram então habitualmente contornados por métodos derivados de uma confiança, com raízes na popularidade dos termos, na delimitação relativa das categorias ou áreas expressas como "a base" (infraestrutura), "a superestrutura”.

O que se percebe é que, se os termos infraestrutura e superestruturas não forem tomados considerando-se a proposição inicial de uma postura epistemológica de Marx, de que as ideias e representações estão "diretamente entrelaçadas" ao desenvolvimento de formas de produção de uma sociedade num momento específico, teremos justamente um instrumental com dois conceitos que contrariam o princípio desta teoria. Afinal, é possível culminar num uso determinista dos termos, pois, como afirma Williams, numa proposição temporal dos termos conjugados a base virá "sempre primeiro" ou, numa metáfora espacial, a "camada final" de qualquer análise sempre será a base (Ibid.), o que talvez não fosse útil para se compreender todos os movimentos contrários desenvolvidos pelas influências do pensamento humano sobre as forças de produção. Afinal, o pensamento não apresenta uma correlação imediata e mecânica com as condições econômicas e, caso o esquema seja percebido de modo tão determinista com seu vetor voltado somente num sentido, qualquer análise histórica que enfatize justamente uma dialética entre os termos implodiria essa concepção - não parece que esse determinismo mecânico de caráter economicista estivesse implícito na singeleza do escrito de Marx, 
muito embora fosse decorrente de uma leitura consagrada dele, a que se convencionou chamar de "marxismo".

Esse uso contraditório dos termos não parece ser tão recente e deve ter recebido irradiações do determinismo cientificista que dominou os meios intelectuais europeus do século XIX. O próprio Engels já teria pressentido esse uso diferenciado dos termos sob a égide das teorias de Marx, como é possível deduzir de uma famosa missiva destinada a J. Bloch no ano de 1890, quando Marx já teria morrido há sete anos (MARX; ENGELS, 2010, p. 103):

De acordo com a concepção materialista da história, o fator que em última instância determina a história é a produção e a reprodução da vida real. Nem Marx nem eu jamais afirmamos mais que isto. Se alguém o tergiversa, fazendo do fator econômico o único determinante, converte esta tese numa frase vazia, abstrata, absurda. A situação econômica é a base, mas os diversos fatores da superestrutura que se erguem sobre ela - as formas políticas da luta de classes e seus resultados, as Constituições que, depois de ganha uma batalha, a classe triunfante redige etc., as formas jurídicas e inclusive os reflexos de todas essas lutas reais na cabeça dos participantes, as teorias políticas, jurídicas, filosóficas, as ideias religiosas e o seu desenvolvimento ulterior até a sua conversão num sistema de dogmas - exercem também sua influência sobre o curso das lutas históricas e determinam, em muitos casos predominantemente, a sua forma. Aqui está presente a interação de todos esses fatores, na qual, através de toda a multidão infinita de casualidades (ou seja, de fatos e eventos cuja conexão interna é tão remota ou tão difícil de demonstrar que podemos considerá-la como inexistente, que podemos subestimar), acaba sempre por impor-se como necessidade o movimento econômico. Se não fosse assim, aplicar a teoria a uma época histórica qualquer seria mais fácil que resolver uma simples equação de primeiro grau.

O mais grave problema da conjugação determinista entre superestrutura e base encontra-se, a propósito, no sentido complexo que o 
termo "determinar" assume aqui, e, caso ele não seja tratado teoricamente de modo dialético, o determinismo economicista e mecânico parece ser inevitável. Raymond Williams também parece concordar que o ponto nevrálgico é sempre a relação de determinação entre as circunstâncias materiais e as formulações superestruturais, que pode ou assumir um significado de relação causal teleológica de cunho mecanicista entre duas ordens distintas em que uma ordem anterior prefigura a posterior de modo previsível, ou também, como prefere, pode assumir o significado de "impor limites e exercer pressões, seja por alguma força externa ou por leis internas de um desenvolvimento particular" (WILLIAMS, 2011a, p. 44; 2003, p. 103-107; 1979, p. 79-92). Ao buscar encontrar o sentido original do termo "determinar", de acordo com seu uso no original alemão de Marx no prefácio de 1859, por exemplo, ele assume duas acepções: a de estabelecer limites, num sentido negativo, e de impor pressões, num sentido positivo. Como se as condições materiais de produção de uma ideia estabelecessem um limite do qual seria impossível o pensamento humano ultrapassar, mas, ao mesmo tempo, fossem possibilidades, condições reais, que definem nossas ações, ou impõem pressões. Conforme diz (Williams, 1979, p. 91):

Em todo um processo social, essas determinações positivas, que podem ser experimentadas individualmente, mas que são sempre atos sociais, na verdade com frequência formações sociais específicas, têm relações muito complexas com as determinações negativas que são experimentadas como limites. Pois elas não são apenas pressões contra os limites, embora tais pressões tenham importância crucial. São no mínimo também pressões derivadas da formação e do impulso de um determinado modo social: com efeito, uma compulsão de agir de formas que o mantêm e renovam. São também, e vitalmente, pressões exercidas por formações novas, com suas intenções e exigências ainda não percebidas. A "sociedade" não é nunca, então, apenas a "casca morta" que limita a realização 
social e individual. É sempre também um processo constitutivo com pressões muito poderosas que se expressam em formações políticas, econômicas e culturais e são internalizadas e se tornam "vontades individuais", já que tem também um peso de "constitutivas".

Formulada dessa forma, para além da "casca morta" que limita as realizações sociais e individuais, mas como um processo constitutivo definidor, a determinação abandona seu aspecto mecanicista e chega ao âmbito das relações humanas concretas, materializadas até às vontades individuais, que são então constitutivas. Nesse sentido, passamos a falar de como essas determinações do ser enquanto existência social se materializam em formas de percepção do mundo na consciência de uma comunidade, na consciência de um indivíduo ou mesmo nas relações sociais de um grupo humano. Ao tratar da consciência, ou do conjunto de ideias e conceitos de mundo que se encontram depositados numa consciência comunitária, adentramos em outro aspecto relevante da teoria marxista para a cultura e para a arte. Afinal, ao tratar de consciência definida de acordo com os pressões e limites impostos pelas condições materiais, estamos inevitavelmente tratando de um dos assuntos mais espinhosos do materialismo cultural, a ideologia. Interpretações mais contemporâneas do termo admitem seu uso com o sentido de "a maneira como os homens exercem seus papéis na sociedade de classes, os valores, as ideias e as imagens que os amarram às suas funções sociais e assim evitam que conheçam verdadeiramente a sociedade como um todo" (EAGLETON, 2011b, p. 36). Mas nem sempre o uso conceitual do termo ideologia esteve de acordo com essa definição, e, tampouco, em todas as recorrências do termo, ele esteve necessariamente de acordo com o princípio dialético do materialismo cultural.

Numa densa obra que busca investigar a história da ideologia como conceito desde o Iluminismo até os nossos dias, Terry Eagleton 
(1997) exibe a complexidade do termo, levando em consideração tudo o que de pejorativo e de construtivo pôde representar. Alega que ideologia, por fim, encontra-se de alguma forma materializada em signos discursivos que compõem uma cadeia de sentido constitutivo que mantém relações com as estruturas materiais de uma sociedade, porém (1997, p. 194):

A ideologia é antes uma questão de "discurso" que de "linguagem" - mais uma questão de certos efeitos discursivos concretos que de significação como tal. Representa os pontos em que o poder tem impacto sobre certas enunciações e inscreve-se tacitamente dentro delas. Mas não deve, portanto, ser igualada a nenhuma forma de partidarismo discursivo, discurso "interessado" ou viés retórico; antes, o conceito de ideologia tem como objetivo revelar algo da relação entre uma enunciação e suas condições materiais de possibilidade, quando essas condições de possibilidade são vistas à luz de certas lutas de poder centrais para a reprodução (ou, para algumas teorias, a contestação) de toda uma forma da vida social.

Para alguns teóricos que encontram no uso do conceito de ideologia um problema mais delicado, no entanto, falta às formulações mais correntes sobre esse conceito a resolução de algumas lacunas, insolúveis pelo próprio uso do termo. Uma dessas lacunas seria o fato de que a ideologia pressupõe um sistema relativamente formal e articulado de significados, valores e crenças, de uma forma que se possa definir como "visão de mundo" ou "perspectiva de classe", como se esse sistema pudesse ser abstraído do processo social vivo (WILLIAMS, 1979, p. 112). Para as formulações do conceito de ideologia comumente criticadas, toda a contradição, confusão ou incompletude das ideias de um indivíduo deveriam ser colocadas em prejuízo de um comportamento intelectual típico e excluídas como algo "periférico ou efêmero", ou seja, como exceções a uma "regra": uma abstração da ideologia típica de uma classe social. 
Ora, se estamos a falar de uma consciência materializada numa prática social que é motivada pela manutenção do poder sobre os meios de produção de uma sociedade, como quis Eagleton, caberia um conceito que se expandisse para além de sistemas de ideias formais e típicas e que conseguisse considerar concomitantemente, além de todo o senso de realidade presente num indivíduo, o conjunto mesmo das práticas sociais, mais as instituições - estruturas familiares, lugares, até a língua -, e também uma tradição seletiva que incorpora aspectos "úteis" e ignora as demais práticas sociais à margem. Seria preciso um conceito que evidenciasse como certo embate se encontra materializado nos sistemas de ideias, mas também na disputa pela manutenção ou supressão de um poder social, de acordo com a propriedade sobre os meios de produção. Ou seja, um conceito que analisasse as formas de pensamento considerando em si a totalidade contraditória do processo social.

É com vista na totalidade, não só em sistemas de ideias típicos, mas em todo o processo social, desde os meios de produção até as ideias e manifestações de consciência, que Williams prefere o conceito de hegemonia, de acordo com o que colhe do intelectual italiano Antonio Gramsci. Segundo Gramsci, para pensar a questão das classes sociais na relação de subordinação estabelecida por parte das classes dominantes sobre as classes dominadas, é preciso levar em consideração quais os mecanismos que são empreendidos nessa disputa para que a dominação se perpetue. Para o pensamento de Gramsci, não é possível ver as classes dominadas somente como objetos passivos de manobras em meio a esse complexo nem, tampouco considerar que a coerção do Estado sobre a população seja garantia plena do domínio desempenhado pelas classes dominantes; antes, deve-se procurar compreender quais as estratégias que, quase sempre de maneira infalivelmente eficaz, garantem a perpetuação da dominação, que muitas vezes, inclusive, passa a ser internalizada e reproduzida pelos dominados, incorporadas às suas estruturas de pensamento. 
Por isso Gramsci pensa no conceito de hegemonia, que define como um dos mecanismos hábeis para tal manutenção. Esse complexo conceito em Gramsci está presente em diversas passagens dos $\mathrm{Ca}$ dernos do cárcere e seu uso é absolutamente funcional para tratar de diversos problemas. Ao tratar dos intelectuais orgânicos, por exemplo, Gramsci pensa na colocação desses intelectuais em relação à classe dominante, em termos da hegemonia desempenhada por esta. Segundo $\operatorname{diz} \operatorname{Gramsci}(1979$, p. 10-11):

Por enquanto, pode-se fixar dois grandes "planos" superestruturais: o que pode ser chamado de "sociedade civil" (isto é, o conjunto de organismos chamados comumente de "privados") e o da "sociedade política ou Estado", que correspondem à função de "hegemonia" que o grupo dominante exerce em toda a sociedade e àquela de "domínio direto" ou de comando, que se expressa no Estado e no governo "jurídico". Estas funções são precisamente organizativas e conectivas. Os intelectuais são os "comissários" do grupo dominante para o exercício das funções subalternas da hegemonia social e do governo político, isto é: 1) do consenso "espontâneo" dado pelas grandes massas da população à orientação impressa pelo grupo fundamental dominante à vida social, consenso que nasce "historicamente" do prestígio (e, portanto, da confiança) que o grupo dominante obtém, por causa de sua posição e de sua função no mundo da produção; 2) do aparato de coerção estatal que assegura "legalmente" a disciplina dos grupos que não "consentem" nem ativa nem passivamente, mas que é constituído para a toda a sociedade, na previsão dos momentos de crise no comando e na direção, nos quais fracassa o consenso espontâneo.

Pode-se deduzir daí que a hegemonia para Gramsci é uma função, por exemplo, do Estado (ou sociedade política). Além disso, chama atenção também o que ele denomina de domínio direto, do qual o próprio Estado e o aparato jurídico são expressões. A hegemonia, por sua vez, é composta de um consenso espontâneo à orientação expressa 
pelo grupo dominante, por um "prestígio" histórico, tributário da posição desse grupo dominante e de sua função no mundo da produção material; e também da coerção, que não deixa de ser incluída aqui (mas que não pode ser compreendida como única garantia de controle das classes dominantes sobre as classes dominadas). Ao tratar da hegemonia vista dessa forma, Gramsci transcende o conceito de ideologia como "sistema de ideias de um grupo social", para pensar, sim, nesse sistema, mas também em todas as relações sociais decorrentes dele, e também, e essencialmente, na luta de classes a que uma "ideologia" se presta (ou não). Nesse sentido, não há como pensar nesses sistemas de ideias abstraídos das forças produtivas desempenhadas pelas classes sociais que as colocaram, historicamente, em dominação ou na posição contrária. Ou seja, Gramsci articula a noção de ideologia com todas as implicações e decorrências materiais e históricas de seu uso: articula ideologia e práxis, enfim. Vejamos um comentário ao conceito de Gramsci (COSTA, 2012, s/p):

A hegemonia seria a capacidade de um grupo social unificar em torno de seu projeto político um bloco mais amplo não homogêneo, marcado por contradições de classe. $\mathrm{O}$ grupo ou classe que lidere esse bloco é hegemônico porque consegue ir além de seus interesses econômicos imediatos, para manter articuladas forças heterogêneas, numa ação essencialmente política, que impeça a irrupção dos contrastes existentes entre elas. [...] Logo, a hegemonia é algo que se conquista por meio da direção política e do consenso [...]. Pressupõe, além da ação política, a constituição de uma determinada moral, de uma concepção de mundo, numa ação que envolve questões de ordem cultural, na intenção de que seja instaurado um "acordo coletivo" através da introjeção da mensagem simbólica, produzindo consciências falantes, sujeitos que sentem a vivência ideológica como sua verdade. O pensamento político e ideológico, dessa forma, apresenta-se como uma realidade prática, porque, ao ser compreendido e aceito pelos atores sociais, torna-se poder material, converte-se em ação prática, ou, mais precisamente, em práxis. 
Na abordagem de Raymond Williams sobre a hegemonia, este a considera como um conjunto de práticas e expectativas sobre a totalidade da vida; incluem-se nesse aspecto toda a percepção de um indivíduo sobre si, seus sentidos e sua sensação de realidade. Um sistema de vivência de valores e significações que são experimentados como prática. $\mathrm{O}$ conceito para o teórico inglês deixa as raias de um mero processo de controle e é analisado como uma prática social complexa que atribui aos indivíduos o próprio sentido de realidade. É, como afirma, "no sentido mais forte uma 'cultura', mas uma cultura que tem também de ser considerada como o domínio e subordinação vívidos de determinadas classes" (WILLIAMS, 1979, p. 113). Nessa forma de proposição da hegemonia, Williams procura combater o sentido de superestrutura como uma entidade que pudesse ser analisada em si, abstraída do trabalho e das forças produtivas de uma sociedade. Nesse sentido, acaba por delinear um conceito de cultura que precisa estar essencialmente envolto no jogo de poder das dinâmicas materiais e econômicas de uma sociedade de classes. Segundo diz (1979, p. 114):

O trabalho e a atividade cultural não são agora, em nenhum sentido comum, uma superestrutura; não só devido à profundidade e totalidade em que qualquer hegemonia cultural é vivida, mas porque a tradição e a prática culturais são vistas como muito mais do que expressões superestruturais - reflexos, mediações ou tipificações - de uma estrutura social e econômica formada. Pelo contrário, estão entre os processos básicos da própria formação e, mais, relacionadas com uma área muito mais ampla da realidade do que as abstrações da experiência "social" e "econômica".

Não seria possível, no entanto, se afastar da ideia de superestrutura evitando sua abstração para compreender, contraditoriamente, o conceito de hegemonia como um bloco. É preciso relembrar como a hegemonia constrói seu prestígio historicamente em relação com a 
conquista das forças produtivas (GRAMSCI, op. cit., p. 11). Por isso Williams concebe a noção de uma tradição seletiva, que aglomera suas formas de pensar sobre um todo dinâmico, conforme diz (WILLIAMS, 2011a, p. 54):

Os processos de educação; os processos de uma formação social muito mais ampla no seio de instituições como a família; as definições práticas e a organização do trabalho; a tradição seletiva num plano intelectual e teórico: todas essas forças estão envolvidas no contínuo fazer e refazer de uma cultura dominante eficaz cuja realidade, como algo vivido e construído em nossa vida, delas depende.

Formulado assim, podemos compreender a hegemonia como uma forma dinâmica que depende, necessariamente, de outro processo: o de incorporação. Nesse sentido, a hegemonia torna-se um conjunto de práticas, significados e valores que é dominante e eficaz. Esse conjunto não é uma abstração de um sistema de ideias, é fundamentalmente vivido e, portanto, assume um caráter de realidade para a maioria das pessoas numa dada sociedade e num determinado tempo. Para sua manutenção, no entanto, essa tradição - esse conjunto de valores - torna-se eficientemente seletivo, incorporando em si ao longo do tempo certos elementos e excluindo outros, menos contributivos ou, principalmente, opositores. Essa tradição seletiva, de alguma forma, garante a continuidade da própria hegemonia, uma vez que se responsabiliza por aquilo que Williams chama de continuidade predisposta. Lança mão de todo um repertório de informações e interpretações sobre um passado e um presente que ratifica cultural e historicamente a atuação e desenvolvimento de uma ordem hegemônica. A tradição seletiva mantenedora da hegemonia acaba, por fim, por ser um processo vulnerável, uma vez que muitas vezes é forçada a "pôr de lado áreas inteiras de significação, ou reinterpretá-las 
ou diluí-las ou convertê-las em formas que apoiam, ou pelo menos não contradizem elementos realmente importantes da hegemonia corrente" (WILLIAMS, 1979, p. 119).

Por isso não podemos nos esquecer de que, na formulação original de Gramsci sobre a hegemonia, a manutenção do domínio de uma classe hegemônica dependia de uma coerção estatal e legal ativada quando houvesse crises no comando, ou quando houvesse grupos que não tomassem parte na "consciência espontânea", nem ativa nem passivamente. Isso faz prever que a estrutura hegemônica nunca esgota a complexidade formada pelo conjunto total das práticas humanas, e, portanto, todo o cenário social formado pelas práticas hegemônicas e não hegemônicas é cindido e fissurado, e muitíssimo plural, malgrado $\mathrm{o}$ aspecto lhano que o discurso hegemônico possa atribuir à sociedade. Raymond Williams trata disso ao formular hipóteses a respeito daquelas práticas que estão excluídas da corporatividade hegemônica: são as práticas residuais ou emergentes.

As práticas residuais seriam aquelas que derivam de práticas anteriores, ou do passado. Podem ter sido incorporadas pelas práticas hegemônicas, em parte, ou não, mas, vistas dessa forma, precisam guardar certa distância das práticas dominantes. Por serem relacionadas com práticas do passado, no entanto, não devem ser confundidas com o "arcaico", mas serem vistas em face de sua atualização no presente (WILLIAMS, 1979, p. 125):

O residual, por definição, foi efetivamente formado no passado, mas ainda está ativo no processo cultural, não só como um elemento do passado, mas como um elemento efetivo do presente. Assim, certas experiências, significados e valores que não se podem expressar, ou verificar substancialmente, em termos da cultura dominante, ainda são vividos e praticados à base do resíduo - cultural bem como social - de uma instituição ou formação social e cultural anterior. 
Já as práticas culturais emergentes são aquelas que surgem carregadas de novos significados, novas práticas e novas relações, que são continuamente criados. Existe o perigo constante de não se conseguir discernir entre as formas que são verdadeiramente emergentes - porque são alternativas ou opositoras à cultura dominante hegemônica - e inovações dentro da própria hegemonia, pois, afinal, novos significados são incorporados constantemente às suas práticas dominantes. Por isso é fundamental enfatizar a base social nas quais se inserem novas práticas culturais, e buscar compreender de que forma novas práticas estão relacionadas às novas classes sociais (WILLIAMS, 1979, p. 127):

Uma nova classe é sempre uma fonte de práticas culturais, mas enquanto ainda é relativamente subordinada como classe, essas práticas serão provavelmente desiguais, e certamente incompletas. Isso porque a nova prática não é um processo isolado. Na medida em que surge, e especialmente na medida em que é antes oposicional do que alternativa, o processo de tentativa de incorporação tem início, significativamente.

De uma forma ou de outra, tanto as práticas emergentes quanto as residuais, mesmo quando não assumam o caráter de oposição à hegemonia, estarão na maioria das vezes em posição de alternativas. Justamente por isso é que assumirão sempre a característica de resistência diante de uma forma hegemônica de percepção de mundo que, mesmo que internalizada ou não pelos indivíduos sociais, estará sempre a serviço da manutenção da ordem social necessária para a acumulação do capital e exploração da força produtiva de uma classe por outra. É fundamental, sobretudo, perceber nesse modelo teórico proposto por Williams um caráter de funcionalidade histórica. Isso quer dizer que esse modelo há de servir para análises descritas em balizas cronológicas específicas e de modos totalmente fluídos, nunca como categorias estanques ou abstratas do processo social geral. O que é dominante, pode se tornar residual, bem como aquilo que é emergente pode se 
tornar dominante a qualquer momento, bastando a hegemonia ativar seus mecanismos de cooptação e incorporação. Sobretudo, é preciso enfatizar que esse modelo deve servir à percepção crítica de práticas culturais concretas, que devem sempre ser nomeadas e compreendidas verticalmente em função de sua historicidade.

Buscamos até aqui traçar um caminho desde as proposições iniciais de Marx e Engels a respeito de arte, que afirmavam que qualquer atividade do espírito estaria inevitavelmente relacionada e sujeita às possibilidades materiais de existência, até, a partir disso, investigar quais são as articulações e dinâmicas que estão implicadas na proposição materialista inicial, revisitando tangencialmente categorias teóricas como a superestrutura e infraestrutura, a ideologia, para repousarmos com Raymond Williams e Antonio Gramsci na noção de hegemonia. A partir da formulação de hegemonia, vimos com Williams duas outras possibilidades alternativas contra-hegemônicas, que são as práticas culturais residuais e emergentes. Esse caminho teórico é útil para iluminar um problema caro aos estudos literários, que é precisamente compreender as relações entre literatura e sociedade de modo equilibrado. A história da crítica literária tem demonstrado a existência de um pendular nocivo entre correntes teóricas que ora se voltam mais para a funcionalidade "social" da literatura, ora se voltam em demasia para as funcionalidades textuais da análise literária, como dissemos acima. Fixar esses pontos teóricos é relevante no sentido de não cedermos à forte pressão que tal pêndulo ainda exerce nos estudos literários especializados. Afinal, ao localizar a literatura e a arte diante deste quadro teórico assim formulado, Williams emite um juízo sobre a prática crítica que nos deve ser bastante elucidativo (WILLIAMS, 2010, p. 61):

Agora, se voltarmos à questão cultural na sua forma mais usual - quais são as relações entre arte e sociedade, ou entre literatura e sociedade? - à luz da discussão anterior, temos de dizer, em 
primeiro lugar, que não há relações entre literatura e sociedade nessa forma abstrata. A literatura apresenta-se desde o início como uma prática na sociedade. De fato, até que ela e todas as outras práticas estejam presentes, a sociedade não pode ser vista como completamente formada. A sociedade não está totalmente disponível para análise até que cada uma das suas práticas esteja incluída. Mas ao adotarmos essa ênfase, devemos adotar uma outra correspondente: que não podemos separar a literatura e a arte de outros tipos de prática social de modo a torna-las sujeitas a leis muito especiais e distintas. Elas podem ter características bastante específicas como práticas, mas não podem ser separados do processo social geral.

Em vista do mesmo pêndulo da história da crítica literária, ora voltado em demasia para os "aspectos sociais", ora voltado em demasia para "aspectos formais", Williams encontra o seu ponto de equilíbrio através de um argumentum a fortiori: destrói o pêndulo e dilui a variação entre os extremos. Já que sua formulação teórica está calcada no conceito de uma hegemonia ativa que abarca a um tempo desde o conjunto dos valores simbólicos até as forças produtivas, ergo literatura e sociedade são uma só dimensão composta de modo polimorfo e recíproco, mutuamente complementar, enfim. A dicotomia entre "mais social" ou "mais formal" não pode então persistir numa crítica atenta uma vez que literatura e sociedade são complementares uma à outra, e, incluída num conjunto de práticas sociais, a literatura obedece a "leis" que são homólogas, apesar das especificidades de características enquanto "práticas". Uma crítica literária empenhada nestes conceitos teóricos cuja metodologia considere tal construção epistemológica acerca da literatura, da cultura e da sociedade, deve ser um bom caminho para começarmos a desvelar as relações que devem pautar os diálogos e implicações sociais decorrentes da análise de Neighbours e Os sobreviventes da noite, precisamente em suas relações com a guerra civil moçambicana. Resta ainda, no entanto, tecer considerações conceituais relativas à própria história e cultura em Moçambique, no 
sentido de que possamos ter um terreno maciço para caminharmos em nossas leituras analíticas dos romances, considerando as especificidades locais.

\subsection{Um posicionamento para pensar a literatura em Moçambique}

Por princípio, poderíamos nos ater ao fato de que as literaturas africanas em língua portuguesa são um fenômeno específico no interior do conjunto de comunidades que compõem cada um daqueles países africanos, e que seu surgimento, quando muito datando do final do século XIX, é resultado de um complexo panorama social que se forma a partir dos empreendimentos coloniais ligados ao imperialismo europeu, e que produz novas formações sociais através de processos de incorporação de um contingente populacional às culturas colonizadoras. Ao analisar o quadro histórico que dá origem aos aspectos constitutivos das literaturas africanas de língua portuguesa, não temos como desviar do fato de que a colonização imperialista do século XIX acaba ocupando uma posição fundacional, a partir do qual muitas reações africanas farão com que novas culturas surjam no espaço de destruição causado pela colonização. $\mathrm{O}$ objetivo não deve ser, no entanto, encarar a colonização como única e principal baliza para a análise da história da África, de modo que isso origine, ainda uma vez, um reflexo vitimista que deposite sempre na conta do colonizador todas as tragédias que decorrem no continente. Doutro modo, não se deve ocultar o peso determinante que a colonização assume na composição da África moderna. É preciso, portanto, encontrar o ponto de equilíbrio para tratar desse assunto, assim como solicitava Joseph Ki-Zerbo (1999, p. 35):

O historiador de África, sem ser um mercador de ódio, deve dar à opressão do tráfico de escravos e à exploração imperialista o lugar que elas realmente ocuparam na evolução do continente e que tantas vezes e tão habilmente é minimizado por certos historiadores europeus, com resultados terríveis para a 
mentalidade dos jovens africanos que nos bancos das escolas se alimentaram desses manjares envenenados.

A centralidade da colonização, doutro modo, quando utilizada como recurso de valorização das afetividades que ligam a perspectiva do pesquisador aos possíveis sucessos dos movimentos históricos mais recentes, levou a problemas gravíssimos de periodização e conceptualização de uma provável história cultural de África. A dificuldade extrema que se encontra de localização e definição dos sistemas culturais endógenos face às sociedades africanas urbanas da contemporaneidade decorrentes da colonização é um exemplo bastante significativo. Decorrem dois efeitos da centralidade da colonização na perspectiva do estudioso das culturas africanas: i) a fratura entre uma cultura da "modernidade" oposta a uma "tradição" africana, e ii) uma periodização simplista de toda a história do continente em três componentes ou etapas, quais sejam, pré-colonial, colonial e pós-colonial.

$\mathrm{O}$ primeiro efeito apresenta-se sempre como uma tendência latente, derivada, quiçá, da antropologia colonial, em isolar a África subsaariana num complexo autônomo e atomizado, que seria a África da "tradição", a qual, doutro modo, poderia ser chamada de "África profunda”. Convencionou-se atribuir a essa África da "tradição" certos chavões, palavras-conceito autoexplicativas que serviriam para definir per se o estatuto de culturas totalmente díspares: exemplos desses chavões são a "oralidade", pretensa essência cognitiva de toda a África subsaariana, ou também a "ancestralidade", que num arrojo mais ambicioso que qualquer antropologia estruturalista pode ser estendida como um valor humano a toda a África. Exemplos como o largo trânsito de uma cultura africana escrita em língua árabe, ou a existência de um alfabeto africano etíope devem ser descartados de uma análise dessa "tradição" justamente por sua ascendência semítica, e, portanto, "não africana", diversas outras formas de escrita e transmissão de conhecimento através da cultura material, tudo isso é desprezado em 
favor da tal "oralidade". Contrária às inúmeras dinâmicas históricas que marcam um complexo trânsito entre a porção norte do continente e a sua porção sul, e contrária também a uma visão que constata que a África, em suma, nunca esteve isolada na sua solidão obscura, mas sim, alimentou relações com inúmeros outros espaços (a região sudanesa com o Oriente Médio, a porção norte integrada ao complexo mediterrâneo, a África Austral com a China, a Índia e regiões da Oceania, etc.), essa visada busca identificar nesse "continente da tradição" uma harmonia autônoma, pura e independente, profundamente perturbada pela chegada de um colonizador que introduz em África todos os males. Esse tipo de pensamento acabou repousando nos usos mais extremos de um conceito de "tradição africana", que há muito tem sido questionado.

O antropólogo da Universidade de Abomey-Calavi, no Benim, Obarè Bagodo, considera como marco desse questionamento à ideia de uma "tradição africana" o seminário realizado em Cotonou entre 1987 e 1988, na então Universidade Nacional do Benim, cujo tema era, apropriadamente, Les savoirs endogènes: pistes pour une recherche, cujos resultados seriam publicados posteriormente em forma de um livro de autoria coletiva organizado por Paulin Hountondji, e editado pelo CODESRIA em 1994. Segundo Bagodo (2012, p. 53), entre os resultados obtidos naquele seminário, saltava à vista o fato de que os participantes se propunham "(i) a reconhecer que o adjectivo 'tradicional', mesmo quando se apresenta entre aspas, é inadequado, para não dizer depreciativo, e (ii) a preferir o epíteto 'endógeno'”. Para justificar os motivos que levavam os estudiosos a essas conclusões, Bagodo cita textualmente a alocução de Hountondji, que transcrevemos aqui (HOUNTOUNDJI, 1994, p. 13, apud BAGODO, id., ibid.):

O adjectivo "tradicional" não é inocente senão aparentemente. Utilizado de forma espontânea, por oposição a "moderno", veicula a ideia obscura de um corte radical entre o antigo e o 
novo. Atira, assim, o antigo para um quadro estático, uniforme, sem história e sem profundidade, em que todos os pontos parecem rigorosamente contemporâneos, reservando para a categoria do moderno o prestígio da mudança, ou, numa palavra, da historicidade.

A dissertação de Obarè Bagodo investe pesado no sentido de, cada vez mais, desconsiderar os repertórios culturais africanos como uma "tradição", oposta a uma "modernidade", e sim, como saberes e saberes-fazer endógenos, passíveis de processos de atualização, automodernização, e reciclagens próprias e dinâmicas consoantes ao tempo e ao espaço em que se inserem - ou seja, atribui-lhes exatamente uma historicidade que o conceito de "tradição" parece não poder abarcar até certo ponto. A essa oposição aparente entre modernidade e tradição, Bagodo chama de "falsa antinomia" (id., p. 54), buscando, por sua vez, historicizar mesmo sua origem a partir do decreto proferido pelo imperialismo europeu "triunfalista, condescendente e egoísta", num processo que durou do século XVI até o XIX, de que as outras culturas que encontrava em sua aventura colonial "não passavam de tradicionais, condenadas a uma extinção irrefragável” (2012, p. 55). A mesma antinomia de origens coloniais parece ter sobrevivido a todos os impulsos descolonizadores das ciências e das epistemologias, indo depositar-se numa palavra de "aparente inocência", qual seja "a tradição", oposta à modernidade.

O outro efeito é a caracterização de todas as culturas africanas endógenas como "pré-coloniais", o que coloca a colonização no centro da periodização como um intervalo cunhado de "colonial", e o restante da história de África após o alvorecer das independências como o "pós-colonial". A definição de tal periodização dessa forma encontra problemas seríssimos de ordem antropológica, sociológica e mesmo histórica. Ainda que aceitemos a definição do colonialismo europeu ligado ao imperialismo do século XIX como "situação colonial", assim 
como foi definida por Georges Balandier (1993, p. 107-131), não é possível, no entanto, compreender a antiguidade das relações entre Portugal e Angola (que datam desde o século XV), por exemplo, como um período especificamente "pré-colonial" (curiosamente, o Brasil e Angola apresentam histórias de colonização muito aproximativas, e o epíteto "pré-colonial" não há de significar muita coisa para a análise da cultura brasileira contemporânea, assim como é usado até hoje para Angola). Outrossim, acreditar que toda a África conspirava numa estabilidade letárgica antes do contato com o colonialismo imperialista é desconsiderar os inúmeros fluxos e refluxos do continente com outras partes do globo, como já evidenciamos. Além disso, todas as vicissitudes dos processos históricos posteriores às independências jamais poderiam ser vistas em bloco, sobretudo quando esse bloco considerasse que o dado "colonial" estivesse superado, como sugere a terminologia "pós-colonial”. Elikia M’Bokolo, que dedica o primeiro tomo de sua magnífica obra África negra: história e civilizações justamente ao período que compreende desde a pré-história do continente até o século XVIII, debate-se com esses conceitos na introdução do volume, justamente buscando subtrair desse período a pecha de “pré-colonial”. Segundo o historiador congolês, ao adotar tal terminologia (M’BOKOLO, 2009, p. 11):

Registra-se, com efeito, pelo menos um erro de perspectiva, quando não um preconceito prenhe de implicações intelectuais, mas também políticas, quando se pretende dar um sentido à evolução muito longa e inacabada de um continente e partir do último século de sua história: o século colonial. Semelhante miopia não se explica apenas pelo fato deste século ser o mais próximo de nós. Deriva também do fato de muitos continuarem a aí encontrar a legitimidade das suas posições atuais. Ora, o mínimo que se pode exigir do historiador é que abstraia, até onde for possível, das pressões afetivas e sociais do tempo presente. De resto, todas as características que as duas lendas da colonização - a lenda 
negra e a lenda dourada - lhe atribuem são encontradas com uma intensidade variável, conforme as regiões e as épocas, no período designado abusivamente como "pré-colonial": abertura aos mundos exteriores; hegemonismos externos e internos; polarizações sociais; pauperização, dependência e desigualdade dos ritmos de crescimento econômico e das formas de desenvolvimento social; alienação, aculturação ou afirmação de personalidades próprias...

Ora, a introdução do prof. M’Bokolo deveria ser o suficiente para derrubar qualquer persistência de romantismo sobre África "tradicional", quando mais não fosse pelo restante do volume dedicado à caudalosa história africana anterior à colonização imperialista (mas não anterior ao contato com o europeu, posto que, como se percebe, é muitíssimo antigo). Esse modelo de periodização é visto em sua própria historicidade pelo prof. M’Bokolo, articulada que está às "afetividades" daqueles que ainda creem na superação da condição colonial como o mais grandioso feito pelos protagonistas africanos. Isso está na base das mitologias nacionalistas que analisaremos com cuidado adiante. Mas também não se pode olvidar o quanto desta periodização ainda carrega consigo de eurocentrismo, uma vez que considera centralmente a colonização, em fim de contas um empreendimento europeu, na centralidade de todos os demais períodos, como analisa a estudiosa italiana Anna Maria Gentili (2012, p. 52), quando diz que essa periodização "sigue estando moldeada, por convención y conveniencia, preponderantemente sobre los sucesos europeos". O que dizer então do "pós-colonial", que se tornou a última moda dos estudos africanos, obrigando ao pesquisador a adentrar numa seara que ainda se debate acerca de ser uma abordagem teórica, uma proposta estética, uma periodização, uma ideologia? Não fosse o almejo filosófico tão empenhado dessa abordagem, que se precipita sobre as tendências pós-estruturalistas que renovam as epistemologias das estruturas-estruturadas, das complexas ontologias sui generis, das essências transmutadas em 
especificidades gnosiológicas nunca antes vistas, senão em África, talvez revisitassem o nome próprio que adotaram para si com alguma crítica mais contundente e com mais historicidade (cf., a respeito dessa crítica, o esclarecedor artigo de Mary Louise Pratt, "Pós-colonialidade: projeto incompleto ou irrelevante?”, 1999b, p. 17-54).

O fato de analisarmos essas categorias clássicas de pensamento sobre África com certo distanciamento crítico tem uma finalidade muito específica neste trabalho: observar as culturas africanas, quaisquer que sejam elas, em vista de suas historicidades - e consideramos então as culturas das sociedades contemporâneas urbanas, das sociedades contemporâneas rurais, as pertenças culturais diversas, do presente e do passado. Não deve ter havido nunca, de fato, nenhum momento de paz idílica e harmonia "tradicional” naquela tal África profunda, uma vez que não é possível encontrar a tal paz idílica em nenhum outro lugar do mundo. Todas as sociedades são dinâmicas, intercambiáveis, mutáveis, conflituosas, humanas, enfim. Não há sentido em se considerar categorias chaves para se pensar África sem um mínimo de estudo específico sobre comunidades, situações e períodos específicos. $\mathrm{Na}$ ausência desse empenho pelo dado material específico no interior da pesquisa, apela-se sempre com uma facilidade absurda pelo abstrato: então denomina-se "tradicional" aquilo que, a bem da verdade, se desconhece completamente. A endogenia das culturas residuais em África não deveria ser vista com tamanho comprometimento.

Nada disso significa, no entanto, que o colonialismo imperialista do século XIX não tenha destruído e desestabilizado todas as condições materiais de existência das sociedades africanas assim como elas estavam constituídas antes do processo do "novo imperialismo" (HERNANDEZ, 2008, p. 76-77). Simplesmente, significa dizer que essas sociedades não estavam constituídas de modo essencialmente harmônico, à revelia do restante do mundo, ou melhor, significa dizer que não podemos dizer isso de modo alheio às historicidades das 
tais sociedades específicas. Significa ainda dizer que não há como criar generalizações sobre essas sociedades baseadas em termos postos de modo pouco articulado às condicionantes específicas e locais de cada caso. Significa, por fim, que uma abordagem histórica das culturas africanas não deveria funcionar como uma cama de Procusto, em que sempre teremos de ouvir os mesmos termos repetidos ad nauseam: tradição versus modernidade, ancestralidade versus relações parentais modernas, oralidade versus escrita, colonizador versus colonizado, etc. Infelizmente, essa incansável repetição de termos abstratos e vazios costumeiramente está em detrimento de análises verticais sobre as dinâmicas sociais e históricas específicas no âmbito dos estudos das literaturas africanas de língua portuguesa.

Sendo assim, cumpre realizar uma análise da forma como essas culturas contemporâneas africanas encontraram condições econômicas para o seu alvorecer, e de que forma elas se apresentaram desde o início como resistências no campo intelectual e artístico às formas de opressão perpetradas pelo colonialismo imperialista europeu. Antes de tudo, no entanto, é preciso localizar precisamente o que se compreende por "colonialismo imperialista". E para isso, baseamo-nos numa interpretação do imperialismo de caráter materialista que considera que capitalismo e colonialismo, por princípio, estão intimamente relacionados. Essa abordagem tem raízes antigas, nem sempre voltadas à questão específica do imperialismo europeu em África, mas conservam sempre a análise histórica com fundamentação econômica (HERNANDEZ, 2008, p. 73-74). Por fim, Marx já estava devidamente atento às movimentações das companhias mercantis francesas e inglesas que, já em meados do século XIX, iam empreendendo largos investimentos na China, na Índia, na Argélia, na Pérsia e em outros espaços que foram igualmente se tornando "coloniais" ou "zonas de influência" à medida que o esforço econômico europeu avançava. Em carta a Engels de 1858, Marx escreve o seguinte (MARX; ENGELS, 1973, p. 297): 
No podemos negar que la sociedad burguesa ha experimentado por segunda vez su siglo XVI, un siglo XVI que, así lo espero, tocará a difuntos para la sociedad burguesa, del mismo modo que el primero la dio a luz. La misión particular de la sociedad burguesa es el establecimiento de un mercado mundial, al menos en esbozo, y de la producción basada en dicho mercado mundial. Como el mundo es redondo, esto parece haber sido completado con la colonización de California y Australia, y con la apertura de China y Japón.

A construção da análise de Marx propõe um paralelismo, tanto no domínio estilístico de sua linguagem quanto no conceito histórico que define, entre um século XVI do passado e outro, no presente, em que os mesmos termos de expansão geográfica e econômica se repetem. Segundo o que previa Marx, se o primeiro século XVI deu à luz a burguesia, através do colonialismo mercantil que estabeleceu um mercado mundial, o segundo século XVI trataria de "tocar a difuntos" essa mesma burguesia. As previsões de Marx eram de que uma revolução que suprimisse definitivamente o capitalismo internacional chegasse às imediações da internacionalização da economia burguesa. Sem entrar no mérito da questão, vale perceber como Marx pôde compreender que o avanço do mundo europeu em direção ao Oriente Médio, à Ásia, à Oceania e à África estava a serviço de um projeto de internacionalização da economia capitalista. Assim, as diversas formas que o colonialismo assumiu nos inúmeros espaços em que os europeus o praticaram estiveram a serviço do capitalismo que então se formava, ou renovava, a partir de uma internacionalização de caráter econômico, sobretudo.

O historiador britânico de inspiração marxista Eric Hobsbawm (nascido em território africano, a propósito) busca compreender esse momento da história europeia, a que ele argutamente chama de "era dos impérios", conjugando uma série de fatores de ordem política, 
ideológica e social a um fator central econômico que, embora não seja o único determinante do colonialismo que derivou do imperialismo do final do século XIX, acaba por ser sempre o princípio e a finalidade desse empreendimento megalomaníaco das potências europeias. Neste sentido, Hobsbawm (1988, p. 100) declara que um motivo "geral" para o novo imperialismo do século XIX teria sido justamente a busca de mercados que, através de esforços de exportação, resolvessem os problemas econômicos relativos à superprodução oriunda das crises europeias da segunda metade do século. Além do escoamento dessa produção excedente, a busca por novas fontes de matérias-primas, bem como o "imperialismo social", são fatores decisivos para impulsionar o empreendimento colonial em terras cada vez mais remotas. Resulta disso que, até o final do oitocentos, um curto número de potências europeias terá distribuído seu domínio em colônias efetivas ou zonas de influência por quase toda a superfície do planeta, criando um gigantesco complexo comercial global (Ibid., p. 95):

Então, o fato maior do século XIX é a criação de uma economia global única, que atinge progressivamente as mais remotas paragens do mundo, uma rede cada vez mais densa de transações econômicas, comunicações e movimentos de bens, dinheiro e pessoas ligando os países desenvolvidos entre si e ao mundo não desenvolvido. Sem isso, não haveria um motivo especial para que os Estados europeus tivessem um interesse algo mais que fugaz nas questões, digamos, da bacia do rio Congo, ou tivessem se empenhado em disputas diplomáticas em torno de algum atol do Pacífico. Essa globalização da economia não era nova, embora tivesse se acelerado consideravelmente nas décadas centrais do século.

\footnotetext{
4 "A partir do momento em que o grande imperialista Cecil Rhodes observou em 1895 que, para evitar a guerra civil, era preciso se tornar imperialista, a maioria dos observadores se conscientizou do assim chamado 'imperialismo social', isto é, da tentativa de usar a expansão imperial para diminuir o descontentamento interno por meio de avanço econômico ou reforma social, ou de outras maneiras" (HOBSBAWM, 1988, p. 105).
} 
Além dos fatores políticos, econômicos e sociais que motivaram a expansão imperialista que motivou o colonialismo, existem os fatores essencialmente culturais que decorrem do empreendimento ao mesmo tempo que o motivam. A cultura hegemônica do período dos impérios esteve num contato nunca antes visto com a imensa miríade de formações culturais absolutamente distintas da europeia e precisou formular posições e ideias em relação ao resto do mundo não europeu que, da mesma forma que formulasse uma concepção para o que poderia considerar como cultura - as organizações da vida cotidiana, de sociedade, a construção de conhecimento de cada comunidade -, precisou criar uma base ideológica, a partir daí, que justificasse a ação colonizadora (HOBSBAWM, 1988, p. 118). É por isso que o intelectual palestino Edward Said pensa no fato colonial oriundo do imperialismo em face da cultura que se debate e se organiza a partir dele (SAID, 1995, p. 40):

Nem o imperialismo, nem o colonialismo é um simples ato de acumulação e aquisição. Ambos são sustentados e talvez impelidos por potentes formações ideológicas que incluem a noção de que certos territórios e povos precisam e imploram pela dominação, bem como formas de conhecimento filiadas à dominação: o vocabulário da cultura imperial oitocentista clássica está repleto de palavras e conceitos como "raças servis" ou "inferiores", "povos subordinados", "dependência”, "expansão" e "autoridade". E as ideias sobre cultura eram explicitadas, reforçadas, criticadas ou rejeitadas a partir das experiências imperiais.

Acerca da reflexão sobre como o imperialismo europeu do século XIX arma condições históricas para o surgimento do discurso moderno a respeito da cultura no Ocidente, Terry Eagleton remonta os conflitos vividos pelo pensamento romântico contra o conceito de “civilização", marcado demasiadamente pela aristocracia iluminista 
e com caracteres evidentemente imperialistas. Desse modo, como analisa, o conceito de cultura a partir do romantismo alemão, Kultur, "tornou-se assim o nome da crítica romântica pré-marxista ao capitalismo industrial primitivo" (EAGLETON, 2011a, p. 22; cf. também WILLIAMS, 2000; 1969) - essa nuance crítica no interior da arte europeia não impediria o agressivo impacto do imperialismo em África, no entanto. A partir dessa fundamentação ideológica baseada nas motivações econômicas que lançaram o europeu em direção da partilha do mundo não europeu no final do século XIX, se seguiu a pilhagem, o saque desmedido, a desorganização das sociedades, o assassinato e inúmeras outras formas de violência que acompanharam todo o colonialismo, desde seu auge na segunda metade do século XIX. Frantz Fanon alerta para essa possibilidade de visualizar o colonialismo, solicitando a referência às razões materiais com as quais foi condicionado (FANON, 1975, p. 40-41):

Parecidas tentativas ignoran voluntariamente el carácter incomparable de la situación colonial. En realidad, las naciones que emprenden una guerra colonial no se preocupan de confrontar culturas. La guerra es un negocio comercial gigantesco y toda perspectiva debe ser relacionada a este criterio. La servidumbre, en el sentido más riguroso, de la población autóctona es su primera necesidad. [...] Por esto se deben modificar sus sistemas de referencia. La expropiación, el despojo, la razia, el asesinato como objetivo se duplican en un saqueo de los esquemas culturales o, por menos, son condicionadas a este saqueo. El panorama cultural es desgajado, los valores burlados, borrados, vaciados.

Justamente por isso é que os pensadores mais radicais da situação colonial não hesitaram em anunciar a "morte da cultura" das sociedades submetidas às transformações de base ocasionadas pelo colonialismo imperialista. Com efeito, ao verem desmoronar aos seus 
olhos inúmeras formas de organização social que suportavam práticas culturais muito específicas, pouquíssimas outras analogias de linguagem lhes restariam senão a figura da morte. Aimé Césaire, por exemplo, reflete (1956, in SANCHES, 2011, p. 258-259):

O mecanismo dessa morte da cultura e das civilizações sob o regime colonial começa a ser bem conhecido. Para desabrochar, toda a cultura precisa de um enquadramento, de uma estrutura. Ora, não há dúvida que os elementos que estruturam a vida cultural do povo colonizado desaparecem ou degeneram devido ao regime colonial. Trata-se, bem entendido, em primeiro lugar, da organização política. Pois é preciso não perder de vista que a organização política que um povo se outorgou livremente faz parte, e num grau eminente, da cultura deste povo, cultura que, por outro lado, ela condiciona. [...] Trata-se da limitação da civilização colonizada, supressão ou do abastardamento de tudo o que a estrutura. Como não nos admirarmos, nestas condições, com a supressão daquilo que é uma das características de qualquer civilização viva, a faculdade de renovação?

É possível considerar a posição de Césaire radical justamente porque ele concebe a cultura colonizada como impossibilitada de renovação após a introdução da cultura colonial nos territórios colonizados. O quadro sociocultural específico a que essa proposta faz referência foi de perceber que, a partir da colonização, as formas de transmissão do conhecimento e constituição social da cultura em África precisariam viver lado a lado com as formas de transmissão do conhecimento europeias, e sua economia de base exploratória, transplantadas para aquele continente por força dos movimentos exploratórios e imperialistas que irradiaram do velho continente em levas consecutivas e intermitentes desde o século XV. Em casos específicos, como o do colonialismo português, por exemplo, certas estratégias de integração da população colonizada ao seio da cultura colonial mostraram produzir grupos sociais distintos, que tiveram impacto político 
bastante relevante para o destino da colonização, nos quais, para todos os efeitos, não ocorreria uma "morte cultural", mas a emergência de novas práticas culturais inscritas no interior dos limites impostos e sugestionados pela sociedade colonial.

O intelectual moçambicano Eduardo Mondlane, pensando a respeito da estrutura social de Moçambique sob o domínio português, demonstra que desde o final do século XIX, quando Portugal completara a conquista dos territórios e conseguira implantar um sistema de administração colonial, dois códigos administrativos entraram em vigor, um legislando sobre a população branca de origem europeia, uma pequena minoria responsável por grande parte das receitas públicas justamente porque detentora de grande parte dos estabelecimentos empresariais e comerciais, e outro legislando sobre uma categoria a que os portugueses chamavam de "indígenas", que se tratava na verdade dos africanos negros, a grande maioria da população do território a quem, por princípio, estava negada a cidadania (MONDLANE, 1975, p. 34). O intelectual guineense Amílcar Cabral afirma que esse tipo de desigualdade oficial fomentada pelo aparato de Estado cria duas classes no seio da sociedade colonial. Por isso não hesita em lançar mão do instrumental teórico marxista que pensa nesse problema em termos da luta de classes (CABRAL, 1976, p. 223):

A característica principal, como em qualquer espécie de domínio imperialista, é a negação do processo histórico do povo dominado por meio da usurpação violenta da liberdade do processo de desenvolvimento das forças produtivas. Ora, numa dada sociedade, o nível de desenvolvimento das forças produtivas e o regime de utilização social dessas forças (regime de propriedade) determinam o modo de produção. Quanto a nós, o modo de produção, cujas contradições se manifestam com maior ou menor intensidade por meio da luta de classes, é o fator principal de cada conjunto humano.

Havia uma brecha, no entanto, uma vez que o grupo dos colonizados era dividido em dois subgrupos: o do africano nativo, o 
indígena, vivendo inserido nas economias de subsistência dos meios rurais (consistindo em 94\% da população de Moçambique segundo Mondlane); e o daquele que era considerado "civilizado", porque estava integrado aos sistemas de referências culturais portugueses, e, abandonando as economias de subsistência rural, vivia de salários, alheio aos sistemas culturais anteriores (MONDLANE, 1975, p. 39). Estas eram as bases do que Mondlane chama de "sistema do assimilado", o qual, na verdade, se prestou a criar minorias aculturadas dentro da sociedade moçambicana. Levantamentos empreendidos por Mondlane mostram que, no início da década de 1960, essas minorias estavam segregadas nas periferias dos centros urbanos vivendo de pequenos salários. É importante ressaltar que a assimilação portuguesa tinha bases históricas antigas depositadas na ideologia da missão evangelizadora do português entre os "gentios", desde as antigas formas de colonialismo. Mas em relação ao colonialismo ligado ao imperialismo do século XIX, a assimilação adquiriu um estatuto jurídico que produziu, durante todos os anos da colonização imperialista, diversas gerações de assimilados na sociedade moçambicana. Não por acaso, as "missões" foram as principais instituições de letramento e aculturação dos "indígenas", grandes formadoras de assimilados, portanto, como analisa o sociólogo moçambicano José Luís Cabaço (2009, p. 107).

Inúmeras alterações sobre a legislação que estabelecia a regulamentação sobre as bases sociais que distinguiam o cidadão português, o assimilado e o indígena ocorreram, sobretudo, devido à pressão internacional após a Segunda Guerra Mundial em relação à autodeterminação dos povos, que foi gradualmente aceita pelas potências, o que tinha relações claras com a emancipação política rapidamente conquistada pelos africanos, a partir da década de 1950 (HOBSBAWM, 1995, p. 218; M’Bokolo, 2009, p. 574; após a década de 1960, só Portugal continuava uma anomalia imperial efetiva em África). A historiografia sobre a colonização portuguesa, no entanto, 
oferece pistas a respeito da incapacidade da empresa colonial portuguesa de oferecer condições de trânsito social para a população nativa. De fato, as diversas alterações da legislação portuguesa sobre as possessões de ultramar ao longo do séc. XX demonstram justamente como Portugal se debatia para encontrar meios mais eficazes de controle das possessões. Valentim Alexandre (2000, p. 193), ao analisar a Lei Orgânica do Ultramar Português, promulgada em 1953, afirma que esta:

[...] não introduz mais do que alterações menores na administração ultramarina; contra a lógica da assimilação, manteve-se o Estatuto dos Indígenas (modificado em 1954), que na prática retirava a cidadania portuguesa à esmagadora maioria da população africana. A essa situação escapavam apenas os "assimilados" - aqueles a quem era expressamente reconhecida a integração nas formas de vida e nos valores da civilização europeia -, que não passavam de uma ínfima minoria $(0,8 \%$ em 1961, quando o Estatuto foi finalmente abolido). Este número reflete bem a incapacidade - e, até certo ponto, a falta de vontade política - de criar as elites que fizessem a mediação entre o poder colonial e as sociedades africanas.

Ora, não será talvez apelar muito perceber nesse complexo quadro da sociedade colonial uma oportunidade de visualizar as propostas de Raymond Williams para a cultura numa sociedade de classes, com as devidas mediações. Afinal, a cultura do colonizador penetra com uma violência desmesurada em território africano, construindo uma classe social específica e minoritária que há de ser proprietária de todos os meios de produção; além disso, essa classe há de contar com a garantia oferecida por um eficaz aparato de Estado (polícia, legislação, sistema jurídico) a favor de um pensamento civilizatório que põe em relevo a sua cultura, alvo maior a ser alcançado na "evolução dos africanos" (essa será, em África, a chamada "máquina colonial”, na célebre expressão consagrada pelo escritor angolano Uanhenga Xitu, 1980), em detrimento de sua cultura anterior, considerada então 
menor, bárbara e atrasada. Não poderíamos dizer que essa classe social formada pelos cidadãos portugueses nos espaços coloniais africanos compõe uma hegemonia cultural, detentora de um conjunto de práticas culturais próprias?

A diferença será talvez justamente que essa hegemonia se constrói mais pela coerção, pela origem bélica das guerras coloniais. Mas um pensamento que justificasse ideologicamente a presença portuguesa em África, mais do que a "missão civilizadora” propagada também por outras colônias, encontrou respaldo em certas formas de pensar muitíssimo antigas dos portugueses: desde o mito do quinto império até a ideia de Portugal como uma nação pluricontinental. No interior daquela camada social que compunha a hegemonia colonial nos territórios africanos, esse tipo de pensamento com certeza foi predominante, como mostra Leila Hernandez ao evidenciar como o ministro das colônias em 1930 enfatizou a "vocação colonizadora" do país como marca da política da ditadura militar (HERNANDEZ, 2008, p. 510).

A outra classe social, a da grande maioria dos africanos com suas diversas formas de organização social, comporia aquilo que podemos chamar de práticas residuais, se considerada a perspectiva da sociedade colonial e, posteriormente, a composição das novas sociedades africanas urbanas dos Estados independentes. Segundo a definição de Williams para o residual, tratar-se-ia justamente de um conjunto de práticas culturais "anteriores", "formadas no passado", mas que se encontram em processos dinâmicos de ativação constante no presente. Embora Césaire insistisse na "morte da cultura" colonizada, vimos como, pelo menos no caso do colonialismo português, houve uma tentativa sistemática de integração de indivíduos do outro espectro social à cultura colonial ocidental, e como isso originou novas configurações sociais no interior da sociedade colonial. Analisaremos o resultado dessa tentativa de integração mais adiante, 
mas, de todo modo, as culturas africanas permanecem ainda hoje em atualização e renovação constante (a antropologia contemporânea entre as sociedades africanas pode ser a prova de como muitas culturas se ressignificaram a partir do colonialismo; cf., p. ex., FRY, 2003; MUNANGA, 1993).

As definições analíticas desses grupos sociais aqui chamados de "classe" não devem significar que o imenso grupo de africanos excluídos dos privilégios da elite colonial (quase a totalidade da população africana) fosse uma massa amorfa e subalterna. Antes, procuram investigar justamente como diante do estatuto econômico da sociedade colonial, que motiva a construção de um aparato jurídico segregacionista, essa massificação era operada justamente pela exclusão e subordinação da força de trabalho aos interesses metropolitanos, integrados aos interesses capitalistas de uma economia mundial. Assim sendo, seria demasiado obtuso não enxergar a movimentação dialética que decorre dos diversos movimentos que o grupo dominante precisou operar para manter sua hegemonia ativa, e, portanto, dependeu de argutas estratégias de incorporação humana e cultural das classes subordinadas. Assim como é igualmente obtuso não perceber que a incursão europeia pela África despertou, desde o início, as mais diversas formas de resistência e subversão.

Com efeito, na proposta inicial de Raymond Williams, há referência à constante possibilidade de uma ordem hegemônica incorporar as práticas residuais. Diante da situação colonial africana, poderíamos investigar duas ordens de incorporação: a primeira refere-se evidentemente à política da assimilação, como estratégia de integração à cultura colonial, mas que visava à neutralização da cultura residual; quanto à outra, trata-se de uma forma política de que Portugal lançou mão para preservar algumas chefaturas originais em favor da manutenção da estrutura administrativa colonial em territórios mais distantes dos centros urbanos (HEDGES; ROCHA, in HEDGES, 1999, 
p. 182-183). Trata-se, efetivamente, de como a colonização portuguesa dependeu do reconhecimento e cooptação de autoridades locais consagradas segundo as referências das culturas endógenas (cada caso é específico, somente a antropologia poderia desvelar as dinâmicas endógenas) para o estabelecimento de um cinturão de autoridades leais e eficientes para a extensão do poder colonial pelo interior do continente. Se, nos primeiros decênios da colonização, o regulato tornou-se cada vez mais obsoleto face à expansão do colonialismo em Moçambique, após a gestão do governador geral José Tristão de Bettencourt, a partir de 1940, que reordenou muitas dinâmicas da exploração colonial no país, os régulos deveriam ter seu poder ampliado, já que, segundo analisam David Hedges e Aurélio Rocha (in HEDGES, 1999, p. 99-100):

[...] o Governador-Geral queria reforçar a posição dos régulos e da ideologia local, de forma a desempenharem o melhor possível, as suas novas obrigações, trabalhando a par com a administração portuguesa na organização da produção e na identificação administrativa da população.

Outra possibilidade de análise é justamente a respeito do tipo de classe que surgiu a partir das tentativas de integração, ou seja, entre os assimilados. Mais ou menos organizados intelectualmente, os integrantes dessa nova classe procuraram alternativas para a condição colonial opressora, a partir da experiência individual, e começaram a formular um pensamento de caráter identitário que pudesse fazer face ante os instrumentos de coerção, tanto os ideológicos quanto os políticos. As raízes desse tipo de pensamento são antigas: vozes dissonantes ao projeto português do ultramar existem desde antes do século XIX. A partir do século XX, no entanto, tomam a forma daquilo que Mário Pinto de Andrade chama de protonacionalismo, e, através de continuidades e rupturas, desembocarão num pensamento verticalmente 
crítico a respeito da colonização portuguesa na África colonizada por Portugal e, posteriormente, na formulação de uma estratégia política de supressão do colonialismo de caráter programático e nacionalista. Segundo afirma Andrade (1997, p. 185-186):

A linha de continuidade situa-se no plano dos temas essenciais do discurso político e da práxis, considerados num outro contexto e carregados de conteúdos diferentes. Com efeito, a problemática inerente ao sistema colonial recolocar-se-á durante largo tempo em termos da dicotomia indígena/ assimilado, da permanência apenas dissimulada do trabalho obrigatório, do esbulho das terras ou do acesso à instrução. [...] Mas o protonacionalismo, na sua essência, foi produtor de um discurso com uma finalidade ilusória: assumindo-se como negros cultos, no molde ocidental, sujeitos da nação portuguesa e legalistas, esses ideólogos [...] não tinham atingido o grau crítico de compreensão lógica do sistema colonial português. [...] E aí reside, precisamente, o ponto de ruptura que será expresso pela geração que fará a sua entrada na cena da história, nos anos imediatos à segunda guerra mundial.

O movimento que levaria à criação de uma intelligentsia africana que conseguisse representar de fato uma ruptura com as manifestações "protonacionais" do início do século, no entanto, parece ter seguido um caminho paulatino, embora baseado sempre na consciência da opressão vivida pelas culturas residuais endógenas em face da hegemonia desempenhada pela cultura colonial. O protonacionalismo está relacionado com a ínfima elite letrada, fruto das primeiras orientações assimilacionistas da presença portuguesa em Moçambique (os velhos assimilados). A consciência crítica sobre a colonização parece surgir concomitante ao surgimento de um novo tipo de assimilação informal que foge ao controle efetivo do aparato colonial, no entanto. Trata-se das populações periurbanas da colônia, em contato franco com os sistemas de referências europeus transplantados pela elite colonial à 
África, uma vez a força de trabalho das populações periurbanas era solicitada para a manutenção de trabalhos serviçais e braçais no interior da sociedade urbana. A relação que esse grupo alimenta com a cultura ocidental parece seguir uma chave mais subversiva, por assim dizer, como explana Cabaço (2009, p. 142): "as populações periurbanas da colônia, juridicamente indígenas, são a evidência de que, a par da política de assimilação decorria um processo espontâneo de mudança cultural, no qual os subsídios de 'modernidade' da sociedade colonizadora eram menos imitados e mais apropriados".

Portanto, a partir da segunda metade da década de 1940, surge uma nova possibilidade de pensamento sobre a questão colonial em África, segundo afirma Eduardo Mondlane (1975, p. 115):

Em Moçambique surgiu uma nova geração de insurrectos, ativos e determinados a lutar pelos seus próprios meios e não dentro dos parâmetros impostos pelo governo colonial. Estavam em posição de examinar outros aspectos essenciais da sua situação: a discriminação racial e exploração dentro do sistema colonial; a fraqueza real do colonizador; e, finalmente, a evolução social do homem em termos gerais, com contraste entre a emergência da luta dos negros na África e na América e a resistência muda do seu próprio povo. [...] A nova resistência inspirou um movimento em todas as artes, que começou durante os anos 40 e influenciou poetas, pintores e escritores de todas as colônias portuguesas. Em Moçambique os mais conhecidos são provavelmente os pintores Malangatana e Craveirinha, o escritor de contos Luís Bernardo Honwana, e os poetas José Craveirinha e Noémia de Sousa.

O que se percebe aí é uma movimentação social e política que continha um clamor forte, representando tendências nacionalistas formuladas a partir de uma consciência identitária e revolucionárias, a partir do ponto de vista de uma consciência política. Mas, ao lado da movimentação social e política, um tipo novo de arte começou a 
ser produzida, empenhada neste tom reivindicatório. É possível interpretarmos esses dados históricos percebendo que esse grupo de pessoas formava uma nova classe que surgiu no seio de uma comunidade africana presente nos subúrbios das grandes cidades coloniais. Com acesso à língua europeia, aos seus instrumentos comunicativos como a imprensa, esse grupo começou a formular um pensamento sobre a situação colonial de forma crítica, e todo esse pensamento crítico estava a par de uma série de práticas culturais que lhe acompanham. Não será demasiado interpretar esse conjunto de práticas culturais como práticas emergentes em face da hegemonia colonial.

Muito se tem dito a respeito do surgimento da cultura contemporânea de África, situada entre as culturas residuais endógenas e a cultura hegemônica do colonizador, não necessariamente dentro dessa chave teórica (MBEMBE, 2009). Existe, no entanto, sempre uma grande dificuldade de situar essa nova cultura tanto em relação à cultura colonial quanto em relação às culturas das sociedades endógenas. Fanon analisa essa relação, tratando da literatura, de uma forma temporal, estabelecendo três etapas de evolução: a primeira, integralmente assimilada, é quando o africano letrado produz obras inteiramente voltadas para a metrópole, e de costas para uma categoria da população a que ele chama de "povo" (os africanos colonizados não inseridos no processo de assimilação - a quase totalidade da população). Num segundo período, as culturas dos africanos não assimilados são relembradas, e um processo de resgate se inicia, em que, segundo Fanon, não deixa de prevalecer um "mal-estar". O terceiro período parece marcar o momento de que tratamos, em que uma literatura surge empenhada num nacionalismo que, além de falar ao povo, vem a convocá-lo (FANON, 2005, p. 255-256):

Enfim, num terceiro período, dito de combate, o colonizado depois de tentar perder-se no povo, com o povo, vai, ao contrário, sacudir o povo. Ao invés de privilegiar a letargia do 
povo, ele se transforma em despertador do povo. Literatura de combate, literatura revolucionária, literatura nacional. Durante essa fase, um grande número de homens e mulheres que, antes nunca teriam pensado em fazer uma obra literária [...] sentem a necessidade de dizer a sua nação, de compor a frase que expressa o povo, de tornar-se porta-voz de uma realidade em atos.

O surgimento dessa classe intermediária entre o antigo assimilado e o "indígena" foi de fato um fenômeno transcendente, surgido em todos os países da África colonizada, e também em outros territórios coloniais. Precisamos aqui enfatizar, no entanto, o caráter empenhado dessa cultura, cujo surgimento foi ensejo das movimentações sociais e políticas que almejaram e construíram as novas nações nos espaços coloniais. Entre a emergência de um conjunto de práticas culturais e a dominância de práticas hegemônicas, no entanto, situa-se um ponto de conflito e embate, como se pode prever. Entre as dificuldades de qualificação de um conjunto de práticas como emergentes, Williams previu justamente o problema de encontrar uma verdadeira oposição à hegemonia como uma característica determinante (WILLIAMS, 2011a, p. 16). As dificuldades de manutenção do colonialismo em África, aliadas à forte oposição representada pela nova classe, deixaram poucas opções para os europeus, conforme afirma $\mathrm{Fa}$ non (2005, p. 273) a respeito do embate:

A cultura nacional é, sob a dominação colonial, uma cultura contestada e cuja destruição é perseguida de modo sistemático. É uma cultura condenada rapidamente à clandestinidade. Essa noção de clandestinidade é imediatamente percebida nas reações do ocupante, que interpreta $o$ amor às tradições como uma fidelidade ao espírito nacional, como uma recusa a submeter-se. Essa persistência em formas culturais condenadas pela sociedade colonial é já uma manifestação nacional.

O conflito, mais do que cultural, tornou-se verdadeiramente bélico quando as pessoas engajadas tomaram consciência de que o 
colonizador era detentor de uma forte máquina repressora e seria incapaz de propor qualquer possibilidade de diálogo. As guerras de libertação que se seguiram em toda a África foram, na verdade, gestoras de novos Estados-nações. Nesse sentido, percebemos o quanto as práticas culturais emergentes surgidas no interior de uma nova classe social explorada e dominada por uma cultura hegemônica são capazes de organizar um movimento de libertação, que, posteriormente, terá a obrigação de organizar um Estado-nação. Amílcar Cabral parece ter previsto esse movimento, pelo que afirma (CABRAL, 1976, p. 224-225):

O estudo da história das lutas de libertação demonstra que são em geral precedidas por uma intensificação das manifestações culturais, que se concretizam progressivamente por uma tentativa, vitoriosa ou não, da afirmação da personalidade cultural do povo dominado como ato de negação da cultura do opressor. Sejam quais forem as condições de sujeição de um povo ao domínio estrangeiro e a influência dos fatores econômicos, políticos e sociais na prática desse domínio, é em geral no fato cultural que se situa o germe da contestação, levando à estruturação e ao desenvolvimento do movimento de libertação.

Podemos ver, portanto, como o colonialismo imperialista contou com uma estratégia cultural hegemônica nos territórios africanos através da imposição do modo de produção capitalista, que foi acompanhado de uma imposição cultural que, quando não renegava totalmente as práticas culturais africanas ao total desprezo, cooptava formas específicas e indivíduos ao processo de incorporação que lhe garantiu, por certo período, sua continuidade predisposta. Ao integrar uma quantidade bastante limitada de africanos ao processo de assimilação, o colonialismo gerou uma nova classe social, intermediária entre si e a grande massa colonizada alienada pelas relações do trabalho, geradora por sua vez de novas práticas culturais emergentes que foram 
capazes de enfrentar, tanto culturalmente, quanto belicamente, o colonialismo português. Dentro desse quadro específico da cultura é que uma literatura nacional nasce em Moçambique, representando uma oposição e uma posição alternativa à hegemonia colonial da cultura portuguesa. Antes de afirmar peremptoriamente que a literatura moçambicana consistirá in totum em uma prática correlata a uma cultura emergente, situada entre a hegemonia da cultura colonial e a residualidade das culturas endógenas do continente, é preciso atentar para a própria localização da literatura face às hegemonias sociais, o que nem sempre é tarefa fácil. Ainda que seja possível considerar que, de fato, houve toda uma literatura hegemônica, vinculada de modo evidente às práticas culturais coloniais nos países africanos de língua portuguesa, e referimo-nos aqui à chamada "literatura colonial", tão bem compreendida pelo prof. Francisco Noa $(2015,1999)$, e que o nascimento de uma literatura empenhada a uma consciência identitária autônoma encontra-se no alvorecer do nacionalismo moçambicano no seio das elites periurbanas, é preciso sempre pensar na historicidade que pode implodir tais posições sociais. Raymond Williams (2011a, p. 63) já teria alertado, afinal:

As artes da escrita e as artes de criação e da representação são, em todo o seu leque, partes do processo cultural em todos os modos e setores diversos [...]. Elas contribuem para a cultura dominante efetiva e são uma dentre suas articulações centrais. Elas encarnam significados e valores residuais, nem todos eles incorporados, embora muitos o sejam. Elas também expressam, significativamente, algumas práticas e significados emergentes, embora alguns dentre eles venham a ser eventualmente incorporados ao atingirem as pessoas e começarem a movê-las.

Assim sendo, até quando essa literatura moçambicana nascente no seio dessa elite periurbana poderá, mesmo, apresentar-se como 
emergente face à hegemonia colonial, e capaz de incorporar as práticas residuais na sua tessitura? E quando todas as peças do jogo tiverem sido remanejadas, após a independência e o advento do Estado-nação independente, será ela ainda emergente, capaz de mobilizar o residual, se a hegemonia agora passa a ser desempenhada exatamente por outra elite? Sobretudo, quando essas elites periurbanas deixam de ser efetivamente uma classe social marginal, e chegam-se com maior ou menor proximidade ao campo do poder, não deixará o emergente de ser, de fato, uma alternativa à hegemonia e passará, por sua vez, a ser hegemônico? Essas perguntas só podem ser respondidas face à história cultural de Moçambique para além da luta anticolonial.

O combate armado pela independência em Moçambique foi formado por diversas correntes anticoloniais agrupadas no início dos anos de 1960 numa Frente de Libertação de Moçambique, a FRELIMO. Essa Frente teve como missão avançar na guerra de guerrilhas que empreendia, desde o norte, na província de Cabo Delgado para o sul do país, conquistando áreas libertadas e, sobretudo, gestar uma nova pátria que chegaria com o fim da luta. Tinha diante de si desafios como a herança colonial espalhada pela cultura dos locais que percorria, sublimadas agora numa presença militar ostensiva contra a qual tinha de combater, e, por outro lado, precisava cada vez mais conquistar a adesão das culturas africanas endógenas, ademais, com suas lideranças eventualmente cooptadas e leais ao colonialismo português, com as quais se debateu até conseguir uma postura definitiva diante delas. José Luís Cabaço chama atenção para o caso específico dos chairmen, lideranças endógenas também opositoras ao colonialismo português designadas para governarem áreas libertadas, com as quais os jovens materialistas que compunham a FRELIMO definitivamente se indispuseram ao longo dos anos de 1960 (CABAÇO, 2009, p. 293):

A prática evidenciou o abismo que, sob a aparente convergência das motivações emancipacionistas, separava as cosmologias 
tradicionais e o projeto de "modernidade" de que os jovens guerrilheiros eram portadores. Chairmen e guerrilheiros divergiam em tudo: na concepção do poder, na perspectiva da organização econômica e social, na estratégia militar e no método de treinamento dos combatentes da liberdade, na participação da mulher no esforço de guerra, na forma de tratar os prisioneiros, na própria definição do que seria "um moçambicano” etc. Os chairmen acusavam a direção da FRELIMO de não respeitar as tradições; os dirigentes acusavam-nos de pretenderem recriar uma estrutura de exploração igual à dos portugueses, substituindo-se simplesmente os colonos.

A experiência dos guerrilheiros socialistas da FRELIMO com os chairmen parece ter sido determinante para que uma concepção sobre as culturas tradicionais fosse definida no seu ideal de nação que ali se gestava. $\mathrm{O}$ desenho específico dos objetivos da luta de libertação ganhava novos traços a partir desse momento (CABAÇO, 2009, p. 295):

O critério de uma autoidentificação com o território, administrado pelos próprios combatentes, encerrava na ideia da FRELIMO, a de Estado-Nação. A construção de uma nova dimensão da identidade cultural ligava-se à convicção dos revolucionários de que a cultura se transformava com a mudança da sociedade e que o fato de tomar nas próprias mãos a libertação e a reorganização autônoma da vida introduziam na cosmogonia das populações uma diferente dimensão da existência e um dinamismo sem precedentes. A luta armada gerava uma ruptura radical, iniciava uma viagem de retorno cujo destino, em discussão, era, todavia, diferente da sociedade tradicional pré-colonial.

O que estamos a ver é que a construção de uma identidade nacional que visasse ao estabelecimento de um Estado na forma como estava sendo proposto no território moçambicano precisava equacionar as diversas formas de pertenças culturais outras que não se enquadrariam com facilidade no modelo proposto pela ala 
dominante da FRELIMO. Ou seja, o nacionalismo revolucionário proposto pela Frente precisaria ser construído em processo, a par da adesão das sociedades endógenas a um pacto consensual acerca de uma nova concepção identitária que transcendesse e superasse as antigas identidades. Evidentemente, isso não era tarefa fácil, sobretudo para um movimento armado que tinha que se ver cotidianamente com a experiência do combate bélico. Nesse sentido, o caminho seguido pela FRELIMO foi justamente do apelo a unidade de um só povo e surgia como um imperativo contrário ao "tribalismo", que percebia nas diversas formas de organização política e social diferentes da organização num Estado-nação um dos muitos inimigos da guerra de libertação. Curiosamente, Amílcar Cabral (1976, p. 225) já o teria prognosticado:

Um povo que se liberta do domínio estrangeiro não será culturalmente livre a não ser que, sem complexos e sem subestimar a importância dos contributos positivos da cultura do opressor e de outras culturas, retome os caminhos ascendentes da sua própria cultura, que se alimenta da realidade viva do meio e negue tanto as influências nocivas como qualquer espécie de subordinação a culturas estrangeiras. Vemos assim que, se o domínio imperialista tem como necessidade vital praticar a opressão cultural, a libertação nacional é, necessariamente, um ato de cultura.

Esse processo de retomada dos "caminhos ascendentes" da sua própria cultura seria um processo bastante específico para Cabral (1976, p. 228), que define:

Para que a cultura possa desempenhar o papel importante que lhe compete no âmbito do desenvolvimento do movimento de libertação, este deve saber preservar os valores culturais positivos de cada grupo social bem definido, de cada categoria, realizando a confluência desses valores no sentido da 
luta, dando-lhes uma nova dimensão - a dimensão nacional. Perante esta necessidade, a luta de libertação é, acima de tudo, uma luta tanto pela preservação e sobrevivência dos valores culturais do povo como pela harmonização e desenvolvimento num quadro nacional.

Se no calor da luta de independência a relação entre a FRELIMO e as chefaturas tradicionais tomaram as formas que vimos, a consolidação do Estado após a independência seguiu a mesma lógica, que agora deveria ser radicalizada e transformada em política de governo, e não mais estratégia de agregação para a composição de uma base social correspondente ao movimento de guerrilha. Desde o início da luta de libertação havia entre os componentes da FRELIMO um ideal marxista-leninista originário tanto da formação intelectual dos combatentes letrados quanto das relações que o movimento mantinha com países que apoiavam o movimento de libertação, dentro do contexto da Guerra Fria e da ampliação de zonas de influência do bloco socialista em oposição ao capitalismo ocidental. No final dos anos de 1960, no entanto, as correntes menos socialistas dentro da Frente representaram uma cisão, definindo-se a ala revolucionária e a ala reacionária (CABAÇO, 2009, p. 312). A morte de Eduardo Mondlane e a ascensão de Samora Machel ao cargo de presidente da FRELIMO, em 1970, marcam a vitória da ala revolucionária e o isolamento da adversária (BRAGANÇA, 1980, p. 48). A configuração desse tipo de nacionalismo revolucionário unitário de cariz marxista-leninista que seria a base sobre a qual se construiria o Estado moçambicano carecia necessariamente de realizar um recorte conceitual sobre a questão ideológica e articular as diversas pertenças sociais das populações do interior do seu projeto. Essa questão até então havia sido somente problematizada diante da questão dos chairmen e posteriormente na cisão do partido pela sucessão de Mondlane. Após a definição do caráter marxista-leninista no encaminhamento político da FRELIMO, 
emerge entre suas políticas de ação a questão do "homem novo" moçambicano. Severino Ngoenha, refletindo a respeito da construção da identidade moçambicana, alega (in SERRA, 1998, p. 24):

A moçambicanidade, isto é, a transcendência das etnias, dos proto-nacionalismos, das religiões pela política, parecia suscetível de ultrapassar a oposição entre uma posição objetiva e outra subjetiva e de manifestar a tensão entre o projeto global da moçambicanidade e a realidade concreta das particularidades nacionais. Contudo, o medo de sucumbir no altar das pertenças étnicas vai levar o projeto moçambicano a criar mecanismos de integração nacional exógenas e, consequentemente, a alienar a força motriz dos grupos e das suas instituições.

A questão do homem novo é na verdade uma reverberação de ideias políticas que vinham das diversas formas que assumiu o socialismo real praticado na União Soviética e na China, além do socialismo da Tanzânia, encabeçado por Julius Nyerere. A FRELIMO, de uma forma ou de outra, deixou-se penetrar por diversas dessas tendências, construindo uma linha de atuação própria, com fortes traços maoístas e stalinistas (MALOA, 2011, p. 87). Tratava-se de uma tendência de ação cultural que, quando alçada a política de governo, representou uma cisão profunda no seio da sociedade moçambicana. A força centrípeta da construção do Estado moçambicano, que se fazia sentir através de uma coerção cultural que privilegiava uma nova forma de identidade, modernizante e cientificista, em detrimento das inúmeras culturas endógenas, vistas agora obstáculos ao progresso econômico e estabelecimento de um poder "popular", acabou por fazer com que o nacionalismo moçambicano fosse mais a expressão de um Estado jurídico que se estava a construir do que, como no início da luta armada, a expressão de um anseio coletivo de libertação nacional e construção de um Estado no espaço colonial (CAHEN, 2005, p. 41). 
Posteriormente, esse tipo de conflito identitário foi utilizado numa espécie de "agressão" dos países limítrofes (a então Rodésia do Sul e a África do Sul, sob o regime do apartheid) para a construção de uma guerra de desestabilização que objetivava a derrubada do governo socialista da FRELIMO, evidentemente com apoios muitas vezes inconfessados das potências capitalistas no contexto da Guerra Fria. Esse conflito, chamado de guerra civil, fez com que a FRELIMO radicalizasse cada vez mais seu discurso, e, à altura, a política cultural do homem novo foi comumente comparada ao assimilacionismo português, justamente pelo desprezo em relação às culturas endógenas, conforme afirma Michel Cahen (2005, p. 59):

Assim, o leitmotiv da Frelimo, "Do Rovuma ao Maputo, um só povo, uma só nação", não foi só um apelo à unidade voluntária, ou mesmo, à unicidade obrigatória: era a negação da própria existência das identidades realmente vividas no seio da população, às quais se opunha o projeto de uma identidade nova, definida geograficamente (Moçambique) e linguisticamente (o português) mas exterior ao vivido das pessoas. A Frelimo, como Portugal, teve de utilizar uma identidade exterior às identidades sociais existentes a fim de legitimar a sua ação. Esta "cultura política" relativa ao projeto nacional é infinitamente mais importante e durável que o recurso instrumental ao marxismo, que, na realidade, nada mais é do que um aspecto contextual deste projeto.

Diferentemente da verificação que pudemos fazer sobre o panorama cultural colonial, em que uma hegemonia colonial portuguesa pôde ser verificada como um conjunto de práticas culturais operantes, em oposição às culturas residuais africanas e, posteriormente, à cultura emergente das elites de africanos letrados que originou o nacionalismo moçambicano, o contexto cultural do estabelecimento do Estado-nação moçambicano parece muito mais complexo. Justamente porque o conjunto de práticas culturais do tipo de socialismo 
praticado pelas populações que estavam mais próximas da FRELIMO tinha um caráter muito mais jurídico e protocolar, um alvo para o qual caminhava a construção identitária empreendida pelo Estado, do que uma realidade vivida por todos os moçambicanos à época. Nesse sentido, o conflito armado que se seguiu, além de marcar as agressões externas no contexto da Guerra Fria, marca justamente a fratura social de Moçambique diante do novo Estado constituído após a independência (GEFFRAY, 1991).

Ao mesmo tempo, não é possível pensar que a proposta identitária e cultural operada pela FRELIMO não desempenhe uma hegemonia: tem ao seu favor a detenção de todos os meios de produção do país, uma vez que, após a independência, estatiza a indústria e fundamenta coletivamente o trabalho agrícola, e inspira a construção de um discurso revolucionário que há de dominar todos os meios de imprensa, a comunicação visual das cidades, mesmo a arte, a literatura e os meios acadêmicos, que viram-se seriamente comprometidos com a visão central proposta pelo governo (VISENTINI, 2012, p. 98); além disso, tem ao seu favor todo um aparato fortíssimo de coerção, como um novo sistema de ensino nas escolas, associação de escritores, uma produção cinematográfica, algum controle da mídia ${ }^{5}$ e também a experiência extrema dos campos de reeducação e de trabalho (THOMAZ, 2008, p. 177). Assim, a radicalidade do Estado em discutir uma proposta identitária que levasse em consideração as culturas africanas acaba por deixá-las justamente na mesma posição de residuais, com a diferença de que, se no colonialismo eram vistas com

\footnotetext{
5 Em relação à produção cinematográfica e ao controle da mídia, vale fazer referência ao documentário Kuxa Kanema (Margarida Cardoso, Portugal, 2003). A película trata da construção de uma revista cinematográfica semanal que serviria para demonstrar os "progressos da revolução" nos locais mais remotos do país. Nele podemos assistir a Luís Carlos Patraquim falar a respeito de como não havia uma "censura" oficial por parte da FRELIMO, mas uma espécie de decoro que todos seguiam voluntariamente.
} 
a indiferença racista e eurocêntrica que as desprezava como um misticismo inferior, agora, durante a construção do Estado, eram vistas como culturas "reacionárias", um "tribalismo inimigo da revolução".

Se pensarmos amiúde na literatura haverá a consagração de um modelo de literatura "oficial" que terá como inspiração o tipo de literatura que invocava o nacionalismo moçambicano em oposição ao colonialismo português e que foi frequente no início das lutas de libertação. Essa nova poesia, de que as coletâneas Poesia de combate (1977, 1979) são exemplo, privilegiará a figura do "poeta guerrilheiro", da poesia produzida no calor do combate de libertação. Salta aos olhos nessas coletâneas o uso indiscriminado da temática do combate como assunto central para os poemas, a linguagem ordinária e simples, com o objetivo de alcançar todos os públicos (quando mais não fosse pelo fato de os poetas serem recém-letrados em língua portuguesa) e pela supressão da enunciação lírica em primeira pessoa, vista então como manifestação de "individualismo burguês". Esse modelo, que passará a ser visto praticamente como um ideal literário, uma norma, entrará em questão justamente a partir dos anos de 1980, quando um novo grupo de pessoas estará disposto a discuti-lo. $\mathrm{O}$ marco dessa discussão é o Concurso Literário de 1980/1981, e um acirrado debate em relação à literatura de que trata Maria-Benedita Basto (2006), num denso trabalho a respeito do tema. É justamente nesse quadro cultural, formado a partir da década de 1980, que se insere uma nova geração de escritores, que distendem o arco do empenho ideológico à poesia revolucionária e produzem uma nova literatura, eminentemente em prosa, versando sobre a mais variada gama de assuntos, inaugurando uma literatura urbana, inovadora e absolutamente inventiva. Cite-se entre esses nomes Ungulani Ba Ka Khosa, Lilia Momplé, Marcelo Panguana, Paulina Chiziane, Nelson Saúte e toda uma geração de escritores pós "revolucionarismo independentista".

A partir de uma abordagem materialista da cultura, que busca investigar justamente quais as relações das práticas culturais com as formas de produção de uma sociedade, procuramos situar as 
hegemonias e contra-hegemonias dentro do contexto cultural da sociedade colonial e em Moçambique, e, posteriormente, na sociedade independente do Estado-nação moçambicano, percebendo as vicissitudes e imbricações que a cultura mantém com a história e com os fundamentos materiais sobre os quais as sociedades se assentam. Ficou-nos claro que, se durante o colonialismo havia uma divisão entre hegemonias e contra-hegemonias culturais que representavam, por fim, classes sociais a que eram correspondentes, na sociedade do Estado independente, pelo menos alguns aspectos que permitem perceber uma hegemonia foram preservados na construção do Estado que teve como premissa a elaboração de uma proposta identitária centrípeta e excludente. Situar a literatura diante desse quadro de uma forma exógena é um imperativo: contrariamente ao peso de uma cultura colonial hegemônica, a literatura nacional moçambicana surge como expressão de um grupo social específico. A partir dessa experiência, um modelo é formado no pós-independência e imposto como norma. Justamente aí surge uma geração de escritores que buscarão novas aventuras estéticas, dessa vez não a favor da construção do Estado, mas justamente se situando na fratura, naquilo que o Estado exclui, ou naquilo que se recusa a reconhecer. Esse é o quadro em que podemos situar a literatura em Moçambique a partir da década de 1990 e no qual se inserem os escritores que propomos analisar neste trabalho.

A tentativa de análise da sociedade moçambicana já no século XXI apresenta muito mais dificuldades: a liberalização da economia que "desestatiza" empresas e cria novas elites empresariais, acompanhada das transições políticas que avançaram do unipartidarismo constitucional para um ambiente que almejava a democracia através de eleições multipartidárias ${ }^{6}$, com certeza metamorfoseia a coerção

\footnotetext{
6 Para uma análise detalhada das liberalizações econômicas e das transições políticas em países africanos anteriormente colonizados por Portugal, cf. Lalá; Ostheimer, 2003; Arrighi, 2006; Cahen, 1995; Jauará, 2004.
} 
estatal sobre o ambiente cultural daqueles espaços, se consideradas formas de coerção que adotavam a violência física e a prisão como forma repressiva. As configurações culturais também mudaram drasticamente: a introdução da televisão aberta em Moçambique fez criarem-se novas formas artísticas mais hegemônicas do que uma literatura crítica a um governo ou não, como, por exemplo, a telenovela, como bem analisa Miguel (2008) e Miguel e Brittos (2004). Com o avanço da educação letrada formal em português para além dos centros urbanos, por mais que esses esforços sejam realizados numa perspectiva intercultural - como analisa Lopes (2004) -, torna o local de permanência das culturas residuais muito mais complexo do que tivera sido antes. Este pequeno trecho fabular do prof. Lourenço do Rosário (2010, p. 57) é exemplar:

[...] houve em qualquer momento da nossa história uma fratura nos métodos de transmissão do saber entre algumas gerações [...]. Uma menina camponesa que entra na escola da sua aldeia sabe que vai frequentar a mesma até ao final das classes que essa escola fornece e que, depois, vai sair e regressar a casa, tendo perdido todos os ciclos de aprendizagem que as gentes da sua aldeia fornecem a quem não vai para a escola. Essa menina, por seu lado, não recebe alternativas, por parte de quem lhe trouxe a escola para a aldeia. [...] A escola veio da cidade, ela vai atrás, mas a escola que vai encontrar na cidade, não tem carteiras e o professor é a própria vida.

Somente após o desenho desse quadro cultural observado pelo prisma materialista é que estamos prontos a propor a questão seguinte: na análise de obras literárias dos nossos escritores moçambicanos, será possível investigar como a obra se estrutura esteticamente em relação à hegemonia identitária desempenhada pela construção e posterior manutenção do Estado? Se as obras se situam num panorama cultural que vai privilegiar justamente as fraturas da sociedade, não 
estarão essas fraturas também sublimadas esteticamente? As contradições, silêncios, ordens, tensões, insuficiências e suficiências moçambicanas de um período estão postos na obra ou a compõem? Como exatamente? Onde se situam as hegemonias e contra-hegemonias na tessitura dos textos literários? Por fim, como poderemos localizar as relações entre a literatura e a guerra especificamente através do estético naqueles textos? 